\title{
Behavior of Laterally Damaged Prestressed Concrete Bridge Girders Repaired with CFRP Laminates Under Static and Fatigue Loading
}

\author{
Adel EISafty ${ }^{1), *}$, Matthew K. Graeff ${ }^{2)}$, and Sam Fallaha ${ }^{3)}$
}

(Received May 27, 2013, Accepted August 14, 2013)

\begin{abstract}
Many bridges are subject to lateral damage for their girders due to impact by over-height vehicles collision. In this study, the optimum configurations of carbon fiber reinforced polymers (CFRP) laminates were investigated to repair the laterally damaged prestressed concrete (PS) bridge girders. Experimental and analytical investigations were conducted to study the flexural behavior of 13 half-scale AASHTO type II PS girders under both static and fatigue loading. Lateral impact damage due to vehicle collision was simulated by sawing through the concrete of the bottom flange and slicing through one of the prestressing strands. The damaged concrete was repaired and CFRP systems (longitudinal soffit laminates and evenly spaced transverse U-wraps) were applied to restore the original flexural capacity and mitigate debonding of soffit CFRP longitudinal laminates. In addition to the static load tests for ten girders, three more girders were tested under fatigue loading cycles to investigate the behavior under simulated traffic conditions. Measurements of the applied load, the deflection at five different locations, strains along the cross-section height at mid-span, and multiple strains longitudinally along the bottom soffit were recorded. The study investigated and recommended the proper CFRP repair design in terms of the CFRP longitudinal layers and U-wrapping spacing to obtain flexural capacity improvement and desired failure modes for the repaired girders. Test results showed that with proper detailing, CFRP systems can be designed to restore the lost flexural capacity, sustain the fatigue load cycles, and maintain the desired failure mode.
\end{abstract}

Keywords: CFRP, repair, prestressed concrete, girder, lateral damage.

\section{Introduction}

Many bridges have been struck by overheight vehicle collisions that may result in bridge failure. In the United States, between 25 and 35 bridges are damaged by colliding overheight vehicles every year, in each state (Fu et al. 2003). Classifications for degrees of damage and applicable repair methods are presented in some literature (Kasan 2009). Also, that reference was updated from NCHRP Project 12-21 (Shanafelt and Horn 1980, 1985). Previous research addressed flexural and shear strengthening of reinforced and prestressed concrete (PS) beams using FRP (Choi et al. 2011; Ibrahim Ary and Kang 2012; Kang and Ibrahim Ary 2012). Several field studies indicated that FRP materials can be used to repair impacted PS bridge girders, after large losses of concrete cross-section and rupture of a small

\footnotetext{
${ }^{1)}$ Civil Engineering, University of North Florida, Jacksonville, FL 32224, USA.

*Corresponding Author; E-mail: adel.el-safty@unf.edu

${ }^{2)}$ Reynolds, Smith, and Hills (RS\&H), Fayetteville, NC 28314, USA.

${ }^{3)}$ Florida Department of Transportation (FDOT), Tallahassee, FL 32310, USA.
}

Copyright $($ The Author(s) 2013. This article is published with open access at Springerlink.com number of prestressing strands (Di Ludovico 2003; Schiebel et al. 2001; Stallings et al. 2000; Tumialan et al. 2001). From the previously conducted research, issues were reported related to premature debonding failures due to either inadequate transverse carbon fiber reinforced polymers (CFRP) anchors or inadequate development lengths (Rosenboom and Rizkalla 2007; Green et al. 2004). The American Concrete Institute reference ACI 440.2R-08 for designing externally bonded CFRP laminate repairs, addresses some debonding behaviors as "areas that still require research" (ACI Committee 440 2008). In spite of the information available on reinforced concrete (RC) repair, data on the behavior of PS girders strengthened with CFRP laminates is limited. Also, few studies address PS members with pre-existing damaged repaired with CFRP (Kasan and Harries 2009; Klaiber et al. 2003; Nanni et al. 2001). The CFRP repair can be used for both flexural and shear strengthening (ACI Committee 440 2008; Grace et al. 2003; Razaquur and Isgor 2006; ElSafty and Fallaha 2013; Shin and Lee 2003; NCHRP R-655 2010; NCHRP R-514 2004). Thirty-four laterally damage RC beams were tested after being repaired with various CFRP configurations to investigate their behavior (ElSafty and Graeff 2011). The performance of repaired beams is limited by possible early debonding and the inability of the CFRP system to transfer stresses into the concrete substrate through bond. The debonding problem associated with FRP sheets hinders the ability to utilize the full tensile strength of the 
FRP, thus decreasing the efficiency of the repair. Therefore, there is a great need to investigate the effectiveness of using CFRP systems that mitigate the debonding problems in the repair of PS girders damaged due to the impact a vehicle collision.

This research addresses specific points of investigation including the effect of using discrete U-wraps on the strain developed in the longitudinal soffit laminates under static and fatigue loading, the optimum configuration of the discrete U-wraps to mitigate debonding strains, the most beneficial level of strengthening (number of CFRP layers), and any design criteria needed for efficient repair systems. This study presents an analysis of the behavior of thirteen halfscale AASHTO type II PS girders under both static and fatigue loading. The laterally damaged PS girders were repaired with different configurations of CFRP repair systems after the concrete integrity was restored. In this research, ten PS girders were tested in static loading and three more girders were tested in fatigue loading to evaluate residual strengths and longevity.

\section{Experimental Study}

In this research, experimental and analytical study was conducted to investigate the feasibility, performance, and most efficient configuration for repairing laterally damaged PC bridge girders using bonded CFRP laminates under both fatigue and static loading. In this study, the experimental work included testing a total of thirteen half-scale AASHTO type II PS girders. Ten girders were tested in static flexure loading and three were tested in fatigue. Two of the ten PS girders represented the control damaged and undamaged samples, without any CFRP. Thirteen PS girders had simulated impact damage imposed on them, concrete repair, two to three layers of CFRP, and U-wraps at various spacing to constitute the repair. Regarding the concrete repair of the cut and damaged area of the girders, the surfaces exposed by cutting were first roughened with chisels to improve bonding quality. These surfaces were then thoroughly cleaned with a water jet and pressurized air, as specified in both NCHRP 514 (2004) and ACI 440.2R-08 (2008). The cleaned cut was filled with a high-strength cementitious repair mortar, and a high-pressure epoxy injection procedure was performed after the mortar set. The procedure resulted in a perfect repair of the concrete cross-section. The spacing between U-wrappings of CFRP was set at a distance of 12 in. (304.8 mm), $20 \mathrm{in.}(508 \mathrm{~mm})$, or $36 \mathrm{in}$. $(914.4 \mathrm{~mm})$. Therefore, the repaired girders varied in both CFRP configurations and levels of strengthening. Ten of the PS girders were tested in flexure until failure under a four point static loading arrangement. Another three repaired PS girders were tested in flexure under a three point fatigue loading. The first girder (PS-1) was a control girder that represents an undamaged and unrepaired specimen. Similarly, the second girder (PS-2) was a damaged specimen which had received no CFRP repair (only concrete repair) representing the lower bound of the tested samples. The remaining girders (PS-3 to PS-5) had both simulated impact damage imposed on them, concrete repair, and two layers of CFRP at various spacing to constitute the repair. The spacing between U-wrappings was set at a distance of $12 \mathrm{in}$. (304.8 mm), $20 \mathrm{in}$. (508 mm), or 36 in. (914.4 mm). The three girders (PS-6 through PS-8) were damaged and repaired with three layers of CFRP at the girder soffit and U-wrappings at spacing of $12 \mathrm{in}$. (304.8 mm), $20 \mathrm{in.}(508 \mathrm{~mm})$, or $36 \mathrm{in.}(914.4 \mathrm{~mm})$. The final two girders (PS-9 and PS-10) were fully wrapped girders (U-wrappings cover entire girder) using two layers of CFRP for the repairs (soffit and U-wrapping). However, the U-wrappings applied to PS-10 were overlapped by inch (25.4 mm), whereas those applied to PS-9 were not overlapped. This was intended to investigate the effect of continuity in the direction opposite to that of the fibers.

Upon the completion of testing the ten half-scale AASHTO Type II girders under static loading and analyzing the results, the three top performing repair configurations from this set were duplicated and applied to the remaining three half-scale girders for dynamic loading tests (PS-11 to PS-13) to investigate fatigue properties of the repairs. The three best performing repairs from the initial ten half-scale girders that were chosen for fatigue testing were the twolayer and three-layer repairs with 20-in. (508 mm) spacing and the two layer with $36-i n$. (914.4 mm) spacing. These configurations were recreated exactly, maintaining the 8-in. (203-mm) wide longitudinal laminates which started at a length of $17 \mathrm{ft}(5,181.6 \mathrm{~mm})$ while reduced six in $(150 \mathrm{~mm})$ per each additional layer applied. Also, the 12-in. (304.8$\mathrm{mm}$ ) wide transverse U-wrappings extended to the top of the web of each girder. Loads, deflection, strains developed along the height of the girder, and strains developed along the span of the girders' extreme bottom fiber were recorded for all girders during their testing. In addition, the modes of failure were also recorded.

\subsection{Test Specimens \\ 2.1.1 Materials}

The CFRP used in this study was a unidirectional carbon fiber fabric. It was used with a saturant, which is an epoxy designed by the manufacturer specifically for the CFRP product. Tables 1 and 2 provide the design values and properties of the reinforcement and CFRP.

\subsubsection{Girder Design}

The investigated PS girders were twenty-foot long and their cross-sectional dimensions represented a half-scale model of an AASHTO type II girder. A four-inch (102-mm) thick deck was cast to simulate a bridge deck composite with the PS girder. On the days of testing, the concrete used for producing the girders had a compressive strength of $\sim 10,000$ psi (68.9 MPa). Each girder was reinforced with a total of five low-relaxation grade 270 seven-wire prestressing strands. In addition, three non-prestressed rebar were provided in the girder flanges and two rebar in the deck topping. Half of the shear steel stirrups extended vertically from the girder to the deck while the other half remained entirely in the girder. They were spaced every 
6 in. $(150 \mathrm{~mm})$ alternating between the two height sizes, providing nearly the maximum amount of shear reinforcement for the cross-section. The girders were designed to be heavily reinforced in shear in order to avoid any premature shear failure that could jeopardize the test results and the investigations into the debonding issues. Figure 1 presents the details of the girder cross-section and the reinforcements.

The lateral damage simulation was achieved by sawing through the concrete of the bottom flange and slicing through one of the prestressing strands. A schematic of this procedure and a picture of the resulting cut are shown in Fig. 2.
To repair the cut, the surfaces exposed by cutting were first roughened with chisels to improve bonding quality. These surfaces were then thoroughly cleaned with a water jet and pressurized air, as specified in both NCHRP 514 (NCHRP R-514) and ACI 440.2R-08. The cleaned cut was filled with a high-strength cementitious repair mortar (Fig. 3a), and a high-pressure epoxy injection procedure was performed after the mortar set (Fig. 3b). The procedure resulted in a perfect repair of the concrete cross-section, as shown in Fig. $3 \mathrm{c}$.

\subsection{Application of CFRP}

Multiple CFRP configurations and strengthening levels were used to repair the girders. The longitudinal CFRP

Table 1 Properties of the CFRP materials.

\begin{tabular}{|c|c|c|c|c|c|c|}
\hline $\begin{array}{c}\text { CFRP material } \\
\text { properties } \\
\end{array}$ & Tensile strength & Tensile modulus & $\begin{array}{c}\text { Ultimate elongation } \\
(\%)\end{array}$ & Density & Weight & Nominal thickness \\
\hline $\begin{array}{c}\text { Typical dry fiber } \\
\text { properties }\end{array}$ & $\begin{array}{c}550 \mathrm{ksi} \\
(3.79 \mathrm{GPa})\end{array}$ & $\begin{array}{c}33.4 \times 10^{6} \mathrm{psi} \\
(230 \mathrm{GPa})\end{array}$ & 1.70 & $\begin{array}{r}0.063 \mathrm{lbs} / \mathrm{in}^{3} \\
\left(1.74 \mathrm{~g} / \mathrm{cm}^{3}\right)\end{array}$ & $\begin{array}{l}19 \mathrm{oz} . / \mathrm{yd}^{2} \\
\left(644 \mathrm{~g} / \mathrm{m}^{2}\right)\end{array}$ & N/A \\
\hline $\begin{array}{c}\text { Composite gross } \\
\text { laminate } \\
\text { properties }^{\mathrm{a}}\end{array}$ & $\begin{array}{c}121 \mathrm{ksi} \\
(834 \mathrm{MPa})\end{array}$ & $\begin{array}{c}11.9 \times 10^{6} \mathrm{psi} \\
(82 \mathrm{GPa})\end{array}$ & 0.85 & N/A & N/A & $\begin{array}{l}0.04 \mathrm{in} . \\
(1.0 \mathrm{~mm})\end{array}$ \\
\hline
\end{tabular}

${ }^{\text {a }}$ Gross laminate design properties based on ACI 440 suggested guidelines will vary slightly.

Table 2 Properties of used steel reinforcements.

\begin{tabular}{c|c|c|c|c|c|c|c}
\hline $\begin{array}{c}\text { Steel } \\
\text { reinforcements }\end{array}$ & Diameter & Bar area & Grade & Young's modulus & Weight & Yield strength & Ultimate strength \\
\hline \hline PS strand & $\begin{array}{c}0.4375 \mathrm{in} . \\
(11.1 \mathrm{~mm})\end{array}$ & $\begin{array}{c}0.115 \mathrm{in.}^{2} \\
\left(96.9 \mathrm{~mm}^{2}\right)\end{array}$ & $\begin{array}{c}270 \mathrm{ksi} \\
(1,862 \mathrm{MPa})\end{array}$ & $\begin{array}{r}27.5 \times 10^{6} \mathrm{psi} \\
(189.61 \mathrm{GPa})\end{array}$ & $\begin{array}{r}0.367 \mathrm{lbs} / \mathrm{ft} \\
(0.5 \mathrm{~N} / \mathrm{m})\end{array}$ & $\begin{array}{c}243,000 \mathrm{psi} \\
(1,676 \mathrm{MPa})\end{array}$ & $\begin{array}{c}270,000 \mathrm{psi} \\
(1,862 \mathrm{MPa})\end{array}$ \\
\hline \#3 bars & $\begin{array}{c}0.375 \mathrm{in} . \\
(9.53 \mathrm{~mm})\end{array}$ & $\begin{array}{c}0.11 \mathrm{in.}^{2} \\
\left(71.3 \mathrm{~mm}^{2}\right)\end{array}$ & $\begin{array}{c}60 \mathrm{ksi} \\
(413.7 \mathrm{MPa})\end{array}$ & $\begin{array}{r}29 \times 10^{6} \mathrm{psi} \\
(200 \mathrm{MPa})\end{array}$ & $\begin{array}{r}0.376 \mathrm{lbs} / \mathrm{ft} \\
(0.5 \mathrm{~N} / \mathrm{m})\end{array}$ & $\begin{array}{c}60,000 \mathrm{psi} \\
\left(345 \mathrm{~N} / \mathrm{mm}^{2}\right)\end{array}$ & $\begin{array}{c}90,000 \mathrm{psi} \\
\left(621 \mathrm{~N} / \mathrm{mm}^{2}\right)\end{array}$ \\
\hline$\# 4$ bars & $\begin{array}{c}0.5 \mathrm{in} . \\
(12.7 \mathrm{~mm})\end{array}$ & $\begin{array}{c}0.2 \mathrm{in.}^{2} \\
\left(126 \mathrm{~mm}^{2}\right)\end{array}$ & $\begin{array}{c}60 \mathrm{ksi} \\
(413.7 \mathrm{MPa})\end{array}$ & $\begin{array}{r}29 \times 10^{6} \mathrm{psi} \\
(200 \mathrm{MPa})\end{array}$ & $\begin{array}{r}0.683 \mathrm{lbs} / \mathrm{ft} \\
(0.93 \mathrm{~N} / \mathrm{m})\end{array}$ & $\begin{array}{c}60,000 \mathrm{psi} \\
\left(345 \mathrm{~N} / \mathrm{mm}^{2}\right)\end{array}$ & $\begin{array}{c}90,000 \mathrm{psi} \\
\left(621 \mathrm{~N} / \mathrm{mm}^{2}\right)\end{array}$ \\
\hline
\end{tabular}

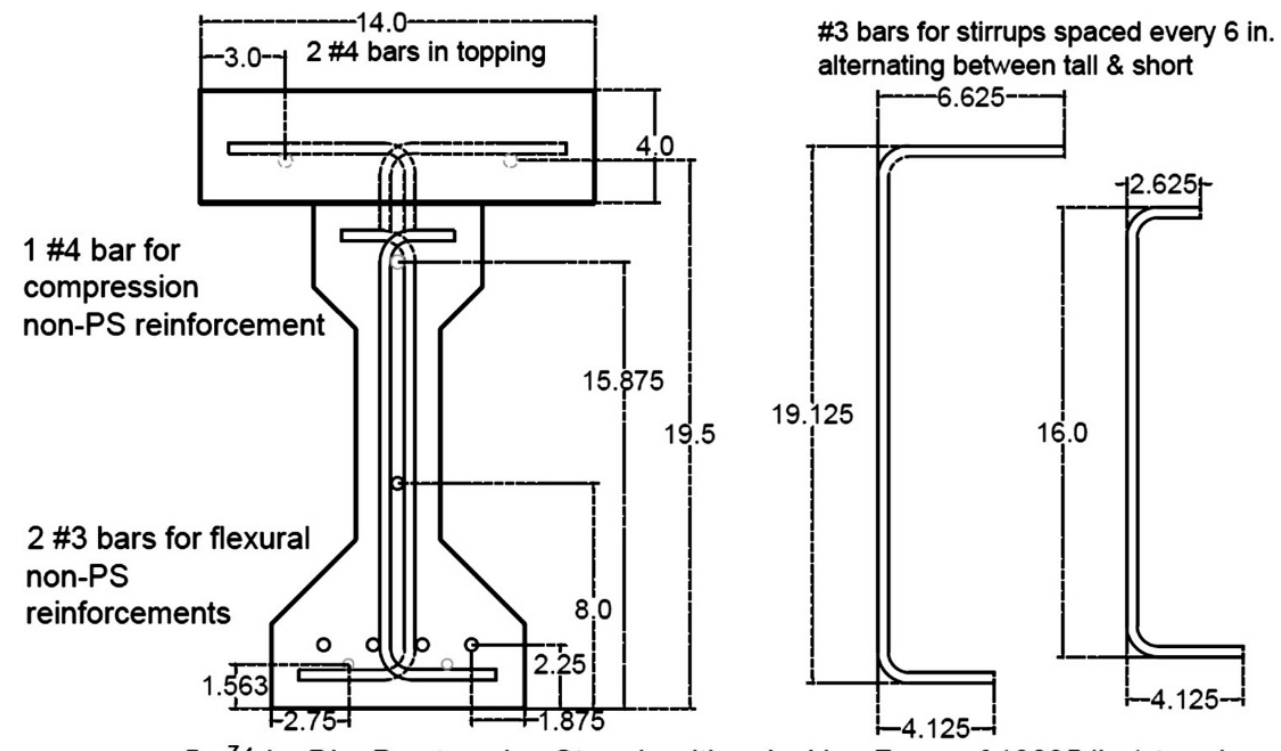

5 - 7/16in. Dia. Prestressing Strands with a Jacking Force of $19895 \mathrm{lbs} / \mathrm{strand}$

Fig. 1 PS test girder cross-section and reinforcements (dimensions in inch; conversion: 1 in. $=25.4 \mathrm{~mm}$ ). 


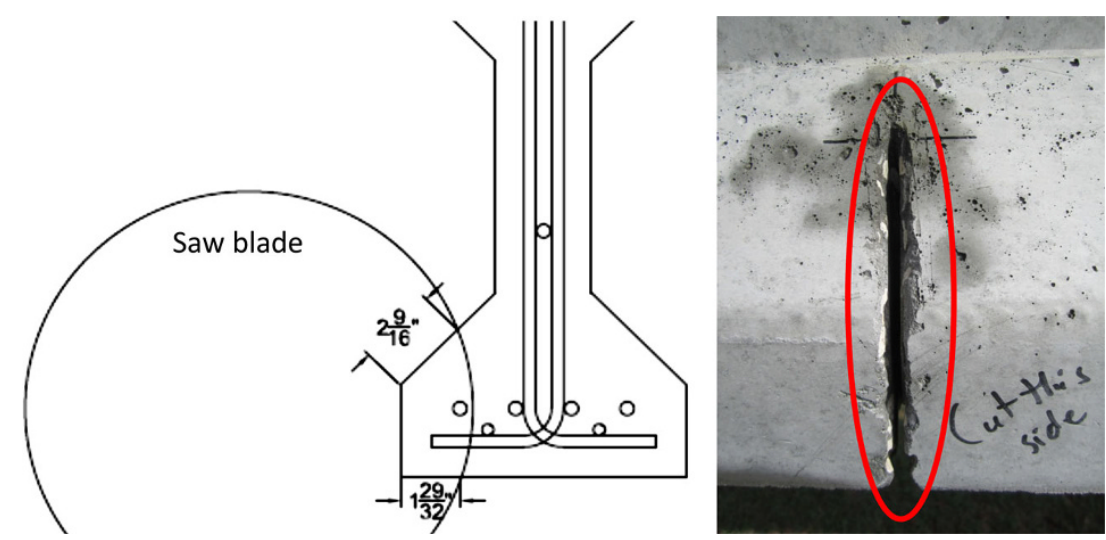

Fig. 2 (left) Diagram of sawing used to simulate damage in the girders; (right) photo showing resulting cut in actual girder sample (conversion: 1 in. $=25.4 \mathrm{~mm}$ ).

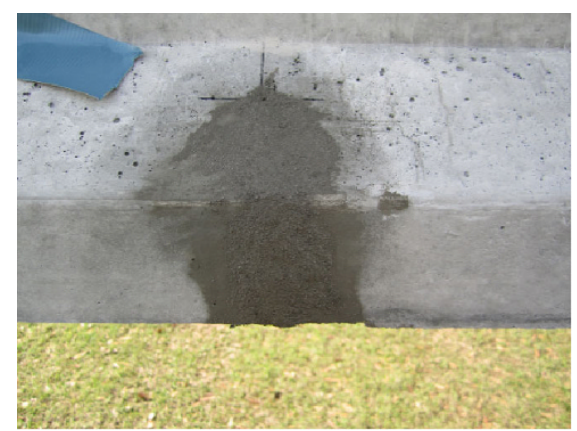

(a)

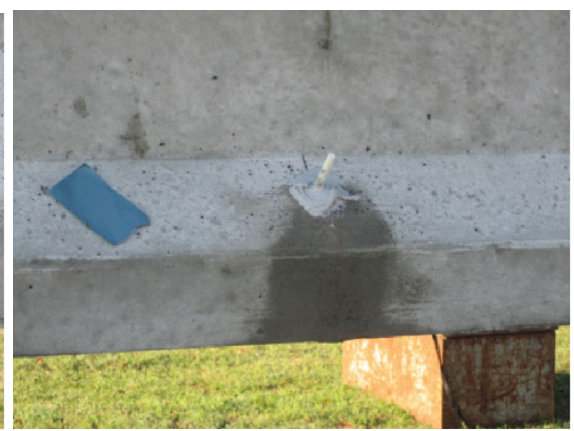

(b)

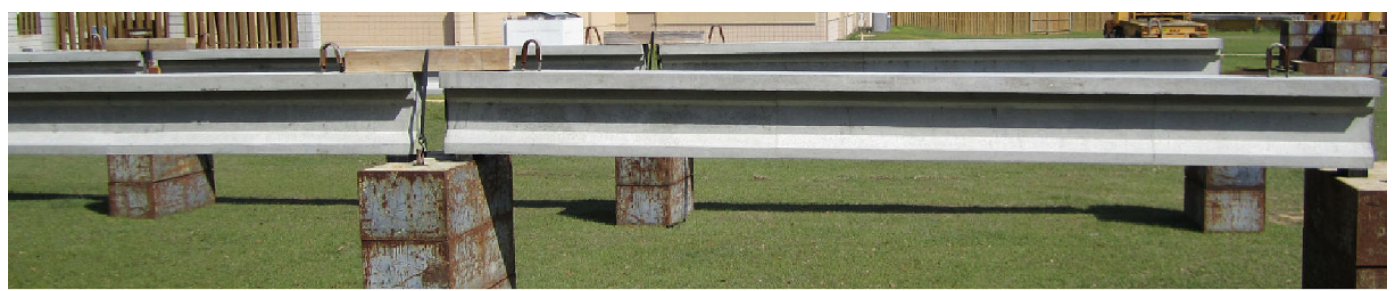

(c)

Fig. 3 Concrete repair of girders with cut strands and damaged concrete. a Cementitious repair mortar. b Epoxy injection. c Repaired half-scale girders.

reinforcement was extended beyond the location of the damage and ruptured prestressing strand a distance greater than the needed full development length of the prestressing strands. On top of the main longitudinal sheets, transverse wet layup U-wrappings were placed throughout the girder length and the length of the repaired region (Fig. 4). The U-wrappings were provided at the termination points of longitudinal CFRP sheet and at several locations between the first cutoff point for the longitudinal CFRP and the damaged region. The U-wrappings encircled the bottom flange and extended the full depth to on each side of the girder. The longitudinal strips were all 8 in. wide and started at seventeen feet long, reducing 6 in. $(150 \mathrm{~mm})$ per each additional layer applied to each girder. The transverse U-wrappings were 12 in. (304.8- $\mathrm{mm}$ ) wide and extended to the top of the web of the each girder. Using U-wraps to anchor FRP longitudinal fiber sheets helps prevent premature delamination failure of the FRP system. Figures 5 and 6 show the CFRP configurations for the half-scale AASHTO type II girders tested under static loading.

As shown in Fig. 5, girder (PS-1) is a control girder that represents an undamaged and unrepaired specimen. Also, girder (PS-2) is a damaged specimen with sawing through the concrete and slicing through one of the prestressing strands. The girder did not receive any CFRP repair and only had concrete repair, thus representing the lower bound of the tested girders. The remaining girders had both simulated impact damage imposed on them and two layers of CFRP at various spacing to constitute the repair. The spacing between U-wrappings was set at a distance of 12 in. (304.8 mm), 20 in. (508 mm), or 36 in. (914.4 mm). Similarly, Fig. 6 displays the CFRP configurations for the remaining girders tested. The girders (PS-6 through PS-8) were damaged and repaired with three layers of CFRP at the girder soffit and U-wrappings at spacings of $12 \mathrm{in}$. $(304.8 \mathrm{~mm}), 20 \mathrm{in}$. $(508 \mathrm{~mm})$, or 36 in. $(914.4 \mathrm{~mm})$. The 


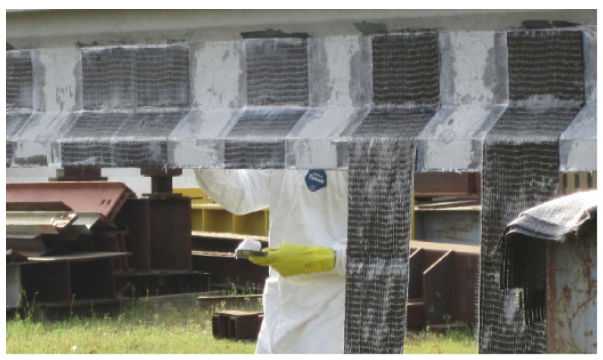

(a)

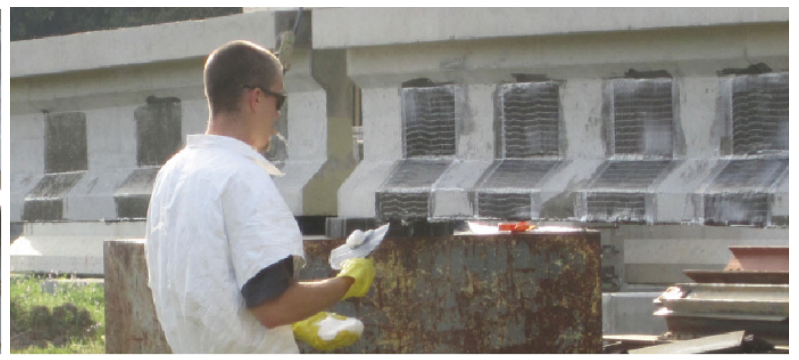

(b)

Fig. 4 Wet layup application of CFRP fabric laminates on PS girder. a Wet layup application of CFRP. b Applying epoxy to CFRP.

PS-1 (Undamaged girder, control specimen)

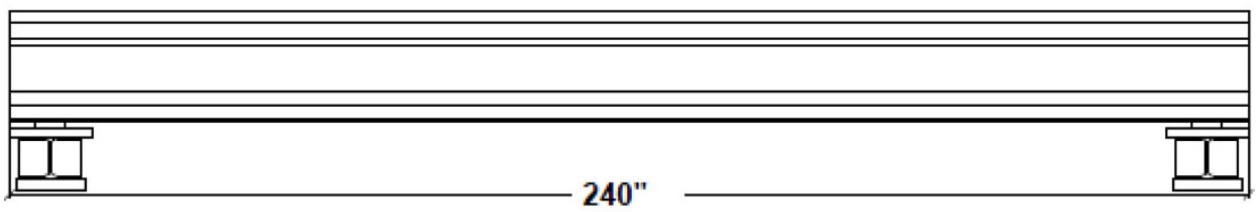

PS-2(Damaged girder second control specimen)

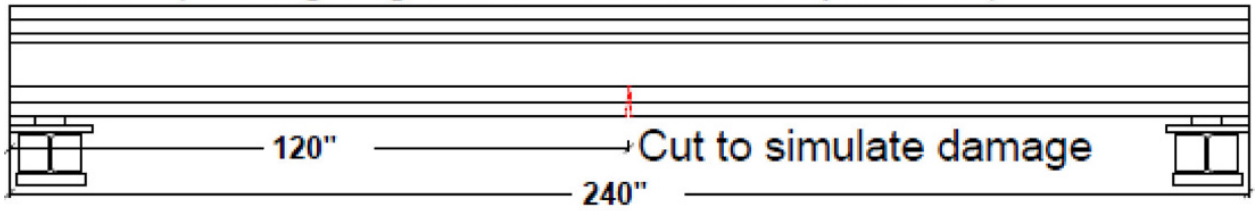

PS-3 (Damaged girder with repair) 2 Layers

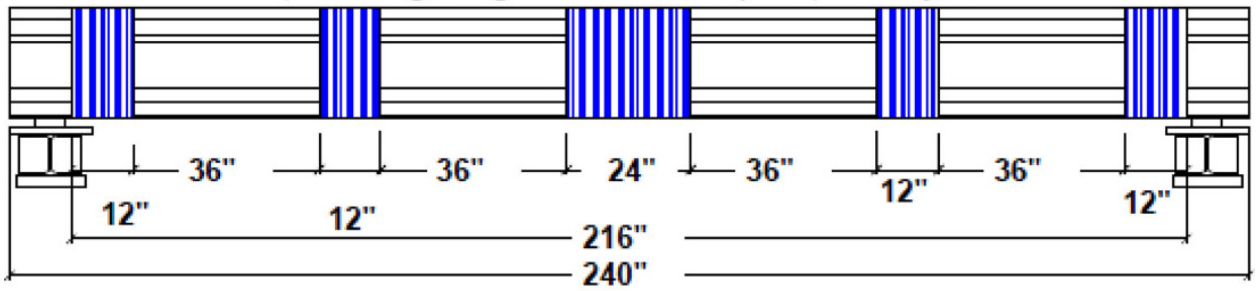

PS-4 (Damaged girder with repair) 2 Layers
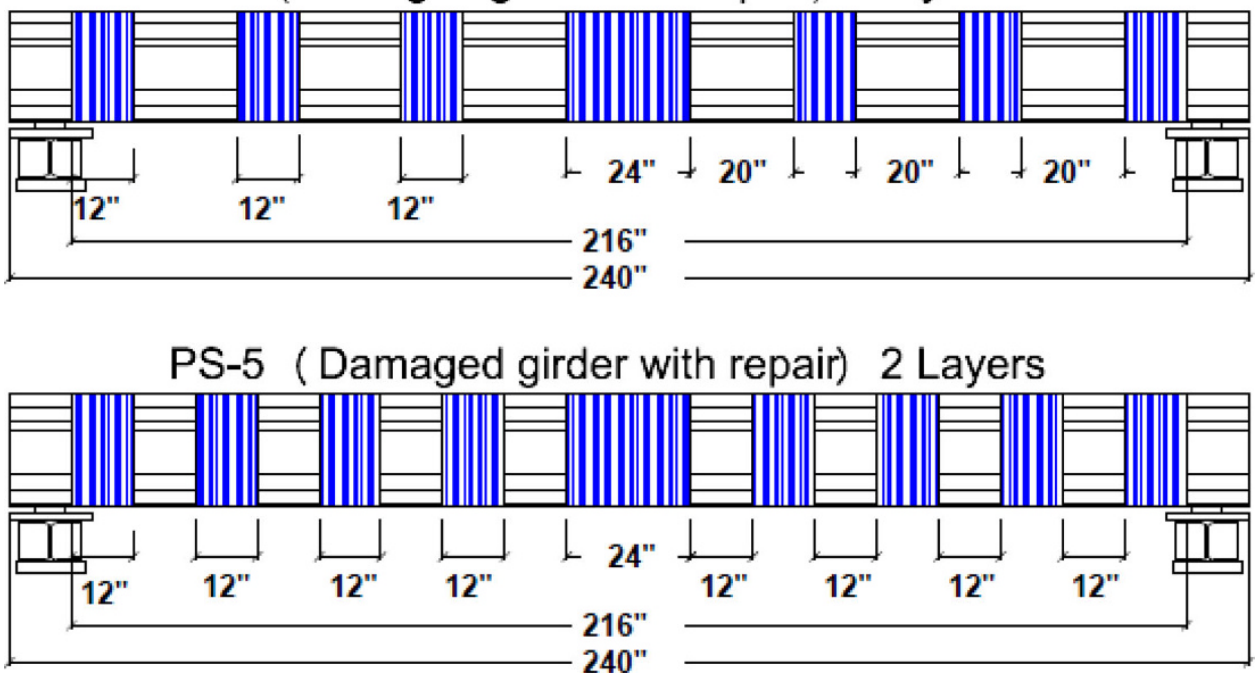

Fig. 5 CFRP configurations used for tested girders PS-1 to PS-5 (dimensions in inch; conversion: 1 in. $=25.4 \mathrm{~mm}$ ).

two girders (PS-9 and PS-10) were fully wrapped girders (U-wrappings covered entire girder) using two layers of CFRP for the repairs (soffit and U-wrapping). However, the
U-wrappings applied to PS-10 were overlapped by an inch $(25.4 \mathrm{~mm})$, whereas those applied to PS-9 were not overlapped. 
PS-6 (Damaged girder with repair) 3 Layers

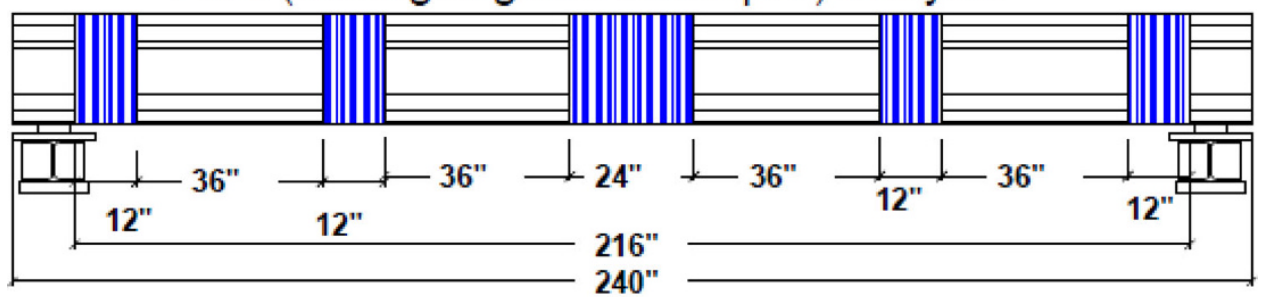

PS-7 (Damaged girder with repair) 3 Layers

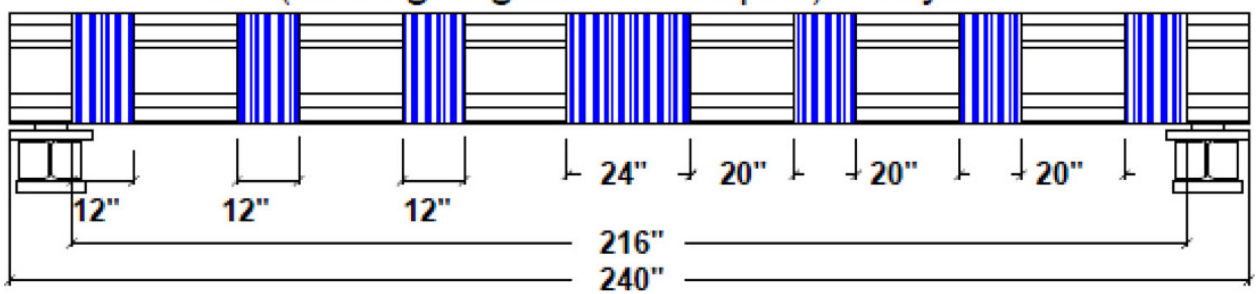

PS-8 (Damaged girder with repair) 3 Layers

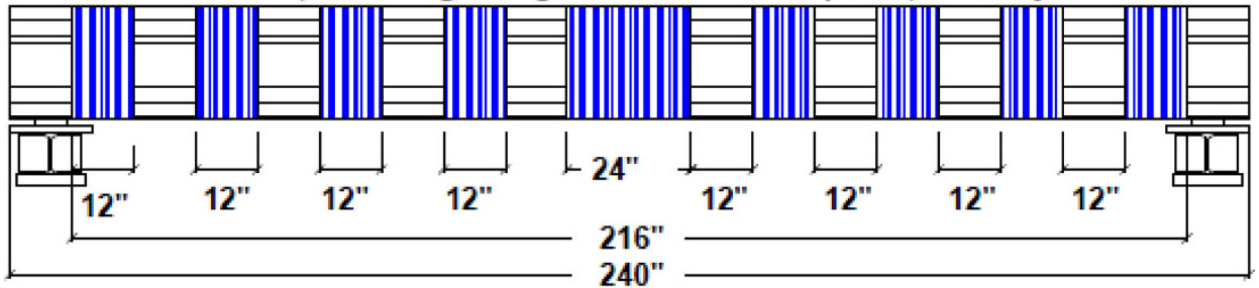

PS-9 (Damaged girder with repair) 2 Layers

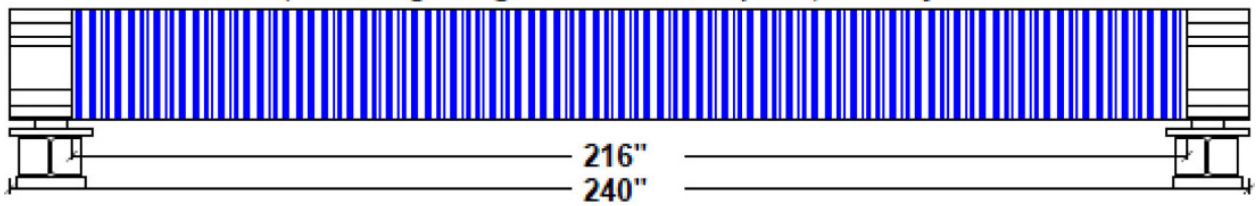

PS-10 (Damaged girder with repair) 2 Layers

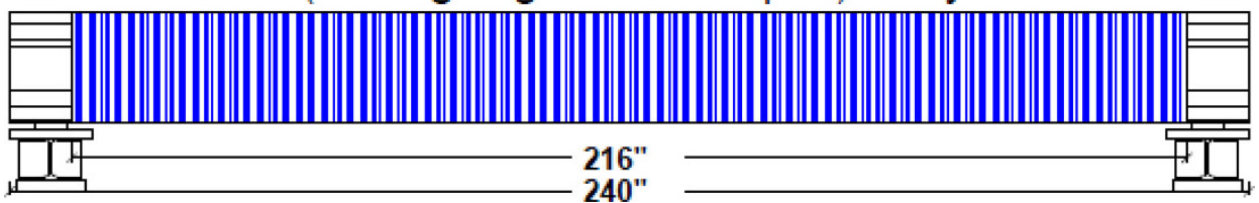

Fig. 6 CFRP configurations used for tested girders PS-6 to PS-10 in static loading (dimensions in inch; conversion: 1 in. $=25.4 \mathrm{~mm}$ ).

Figure 7 shows a sketch of the CFRP configurations used for the three half-scale AASHTO type II girders tested under fatigue loading conditions.

A visual inspection of the CFRP surface was performed for any swelling, bubbles, voids, or delamination, after a day for the initial curing of the resin. An acoustic tap test was performed at the whole covered CFRP surface to identify air pockets and delaminated areas by sound. Defects were repaired as per specifications and most defects were repaired using low-pressure epoxy injection.

\subsection{Test Setup and Instrumentation}

The girders were tested under four point static loading and under a three point fatigue loading at the FDOT structures research lab. The 20-ft-long (6,096-mm-long) PS girders spanned nineteen feet $(5,791 \mathrm{~mm})$ between the centerlines of the bearing pads which rested on stationary supports. The girder static loading was applied using a steel spreader beam resting on another set of two pads with a center to center distance of $50 \mathrm{in}$. $(1,270 \mathrm{~mm})$. Figure $8 \mathrm{a}, \mathrm{b}$ show two girders under loading. The four point static load was applied using a 110 kip $(489.30 \mathrm{kN})$ actuator mounted on a steel frame. On the other hand, the fatigue testing was carried out under a three point loading arrangement using MTS dynamic load actuators. The fatigue testing of the AASHTO II girders was performed using a $55 \mathrm{kips}(244.66 \mathrm{kN})$ and a $110 \mathrm{kip}$ $(489.30 \mathrm{kN})$ hydraulic actuators selected based on their large capacity servo valve which permitted testing of the girder using a frequency of 2-4 Hz. The loading contact area was specified by AASHTO (AASHTO 2004). Neoprene pads were used at girder supports to simulate field supporting conditions. Laser and Linear variable differential transformer 
PS-11 (Damaged girder with repair) 2 Layers

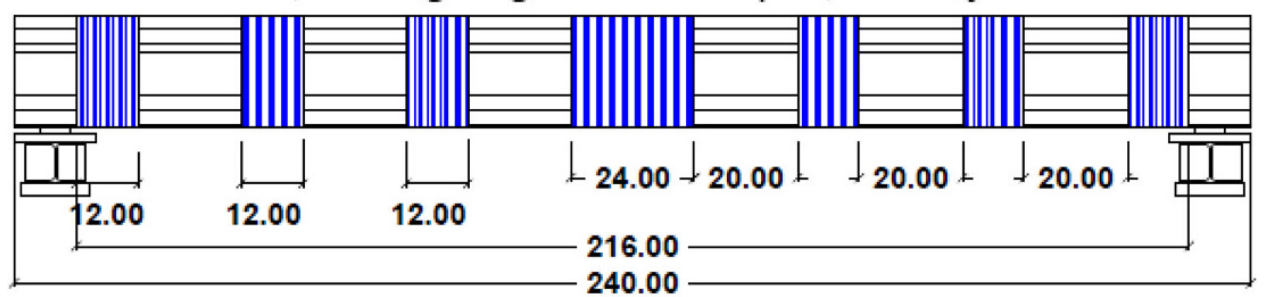

PS-12 (Damaged girder with repair) 3 Layers

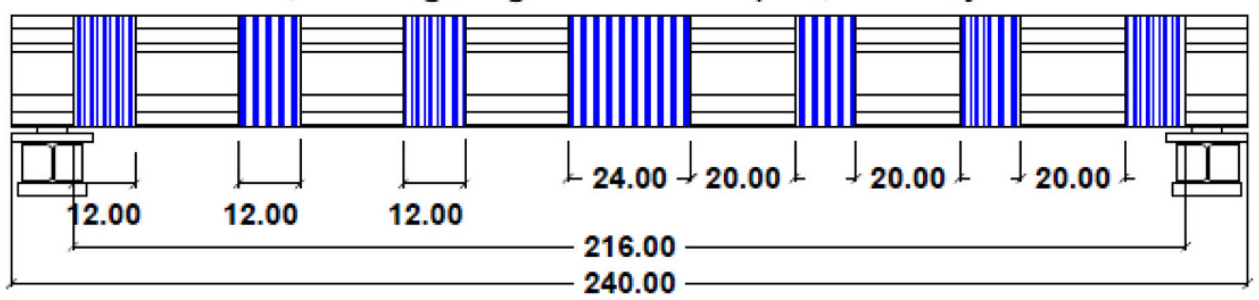

PS-13 (Damaged girder with repair) 2 Layers

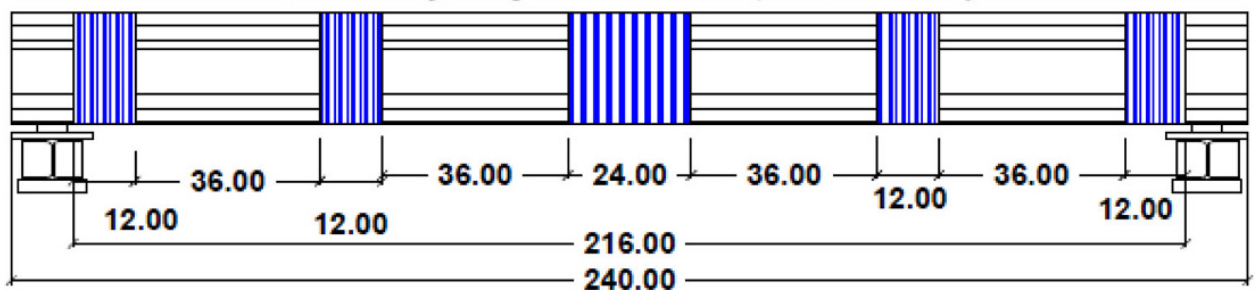

Fig. 7 CFRP repair configuration layout for half-scale PS girders tested in fatigue (dimensions in inch; conversion: 1 in. = $25.4 \mathrm{~mm}$ ).

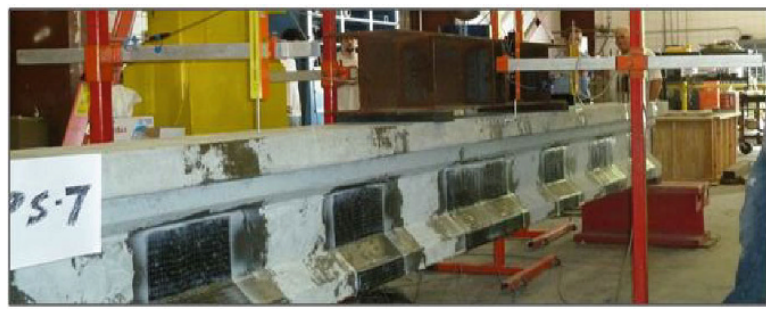

(a)

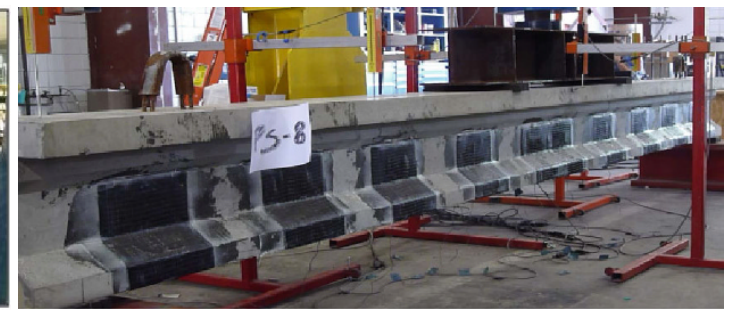

(b)

Fig. 8 Girder test setup diagram and photo of specimen during testing. a Static testing of PS-7. b Static testing of PS-8.

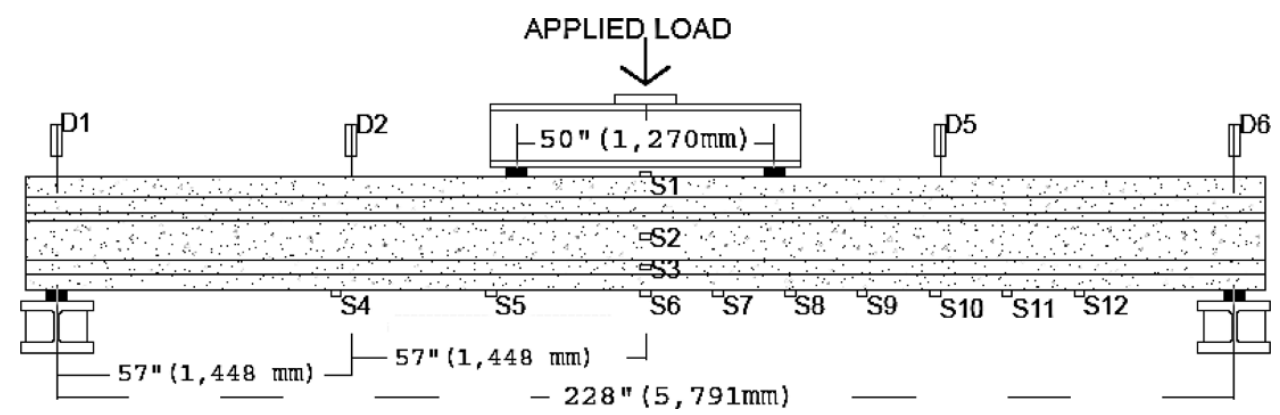

Fig. 9 Schematic of loading set-up and measurement device layouts.

(LVDT) deflection gauges were used. Data acquisition system with multiple channels was used for recording measurements.

Load measurements were recorded by the actuator. The girders were instrumented with six LVDT deflection gages and up to twelve strain gages (30 mm long-120 $\Omega$ ). Two
LVDT deflection gages were positioned at center span on each side of the girder, two LVDTs were placed at girder top surface above the support areas, and the remaining two LVDTs were placed at quarter points of the girder span. On each girder, four of the strain gages were placed along the height of the cross-section at mid-span and the remaining 


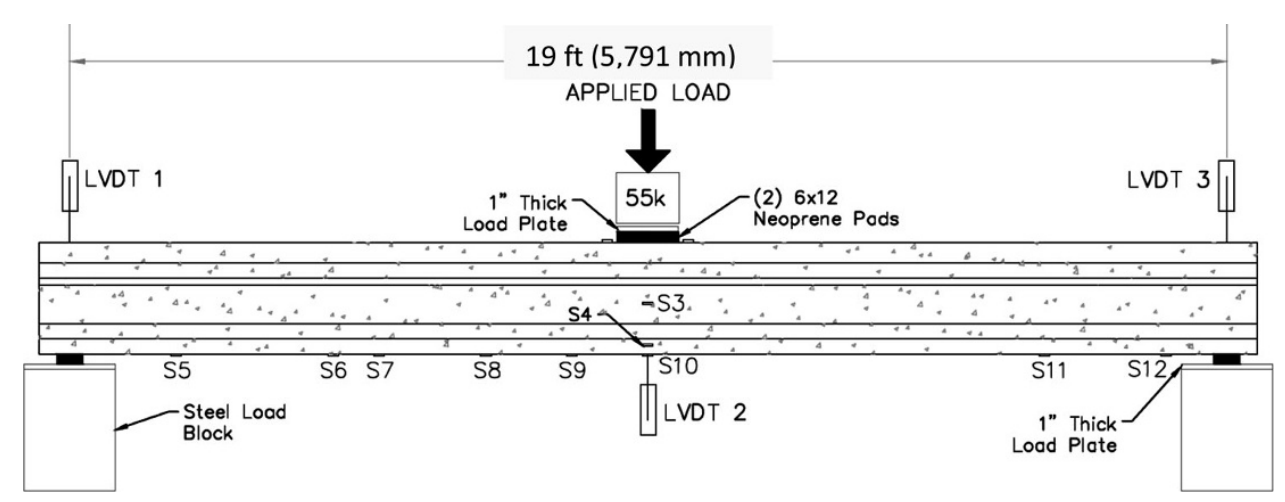

Fig. 10 Fatigue loading setup arrangement for half-scale AASHTO PS girders.

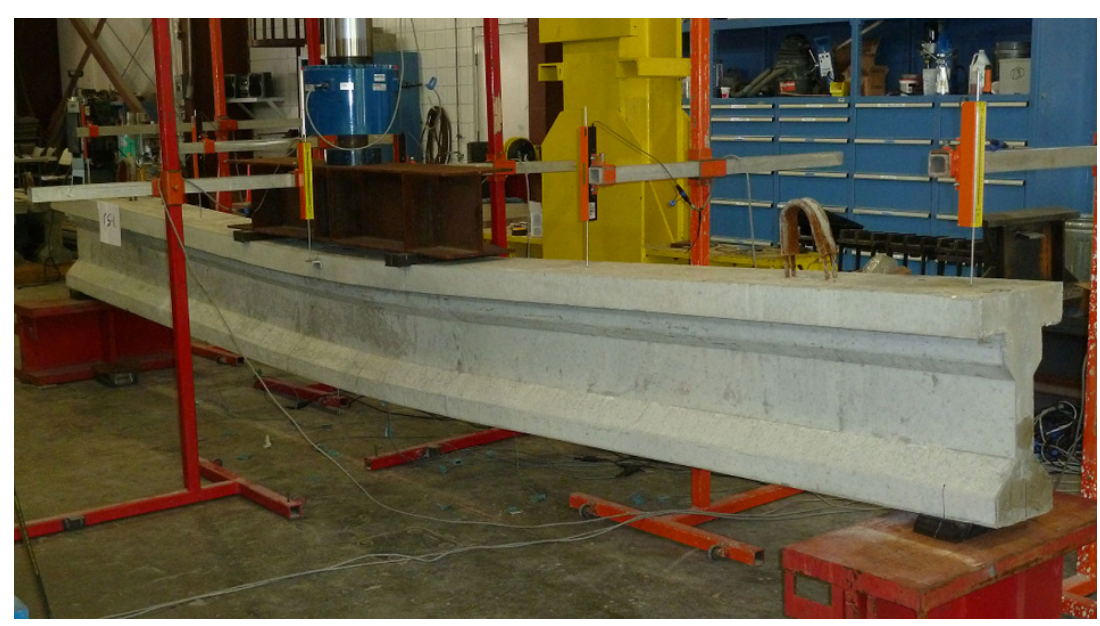

Fig. 11 Half-scale control girder displaying excessive deflection under loading.

strain gages were distributed along the flexural tension side at various locations depending on the CFRP configuration. The general placements of all measurement devices are shown in Fig. 9. The loading arrangement for the fatigue test setup for the half-scale girders is shown in Fig. 10.

\subsection{Test Results and Analysis \\ 2.4.1 Load and Deflection}

Figure 11 shows the control girder with significant deflection under loading. Table 3 shows the maximum loads, corresponding deflections, and increased capacity results from testing. It is shown that a comparison between the failure load of control girder PS-2 (un-strengthened with CFRP) and repaired girders with 2 layers of CFRP shows that CFRP repair enhanced the flexural capacity by a range of 27.53-45.66\% compared to control girder with one less strand. Also, for repaired girders with three layers of CFRP, increases in the flexural capacity were reported to range from 60.24 to $68.74 \%$ compared to control girder PS-2. Increases of $24.85-41.69 \%$ in the failure load were observed for the fully wrapped girders PS-9 and PS-10 compared to the unstrengthened control girder PS-2. The load-deflection behaviors for tested girders are presented in Figs. 12, 13, 14, 15,16 , and 17 .

The results show that the damage of cutting one of the prestressing strands (girder PS-2) resulted in $18.44 \%$ loss in flexural capacity compared to that of the undamaged control girder (PS-1). The CFRP repair of damaged girders (PS-3 to PS-10) restored their capacity and exceeded the capacity of the undamaged control girder PS-1 by up to $37.63 \%$. The results also show that U-shaped discrete strips or wraps of CFRP sheets of girders PS-3 to PS- 8 enhanced the flexural capacity even if the girders were not fully wrapped with continuous wrapping covering the entire girder sides. U-wrappings covered the entire girders (PS-9 and PS-10) using 2 layers of CFRP (soffit and U-wraps). However, the U-wraps applied to PS-10 were overlapped by an inch (25.4 mm), whereas the U-wraps applied to PS-9 were not overlapped. By comparing the two fully wrapped girders (PS-9 and PS-10), an increase in the flexural capacity was observed for the girder with an overlap of its wraps (PS-10). That overlapping of transverse U-wraps is needed to develop proper continuity; even in a direction perpendicular to the direction of the fibers. That is in addition to overlapping the fibers along their length for lap splices, as indicated in ACI 440.2R-08.

The control girders experienced a classic flexural failure initiated by excessive deflection and widening of flexural cracks. The repaired girders experienced either CFRP debonding, CFRP rupture without debonding, or localized debonding followed by rupture of CFRP, as shown in Figs. 18 and 19. Some repaired girders also experienced 
Table 3 Flexure test results for PS girders.

\begin{tabular}{c|c|c|c|c}
\hline Girder & Max load, kips $(\mathrm{kN})$ & $\begin{array}{c}\text { Corresponding deflection, } \\
\text { in. }(\mathrm{cm})\end{array}$ & $\begin{array}{c}\text { \% increase compared to } \\
\text { damaged girder PS-2 }\end{array}$ & $\begin{array}{c}\text { increase compared to un- } \\
\text { damaged girder PS-1 }\end{array}$ \\
\hline \hline PS-1 & $75.87(337.62)$ & $6.94(17.63)$ & $22.60^{\mathrm{a}}$ & N/A \\
\hline PS-2 & $61.88(275.37)$ & $5.38(13.67)$ & 0.00 & $18.44^{\mathrm{b}}$ \\
\hline PS-3 & $90.14(401.12)$ & $2.44(6.20)$ & 45.66 & 18.81 \\
\hline PS-4 & $84.75(377.14)$ & $2.14(5.44)$ & 36.94 & 11.70 \\
\hline PS-5 & $78.92(351.19)$ & $1.61(4.09)$ & 27.53 & 4.02 \\
\hline PS-6 & $100.91(449.05)$ & $2.39(6.07)$ & 63.07 & 33.01 \\
\hline PS-7 & $104.42(464.67)$ & $2.74(6.96)$ & 68.74 & 37.63 \\
\hline PS-8 & $99.16(441.26)$ & $2.29(5.82)$ & 60.24 & 30.70 \\
\hline PS-9 & $77.26(343.81)$ & $1.58(4.01)$ & 24.85 & 1.83 \\
\hline PS-10 & $87.68(390.18)$ & $2.14(5.44)$ & 41.69 & 15.57 \\
\hline
\end{tabular}

a Increase of flexural capacity of PS-1 compared to that of PS-2.

${ }^{\mathrm{b}}$ Loss of flexural capacity of PS-1 due to strand cutting, a percentage of its original capacity.

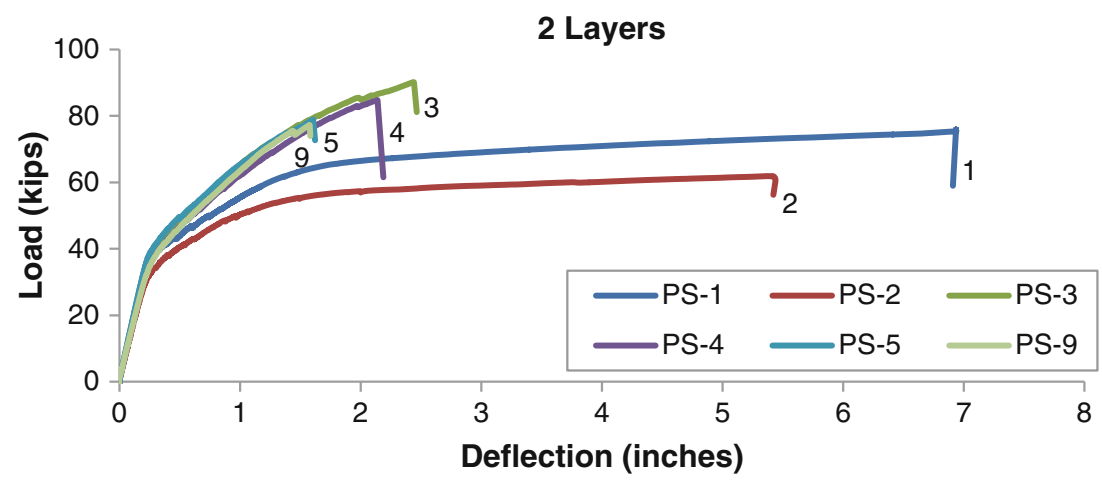

Fig. 12 Load versus deflection for controls and girders with two layers of CFRP (conversion: $1 \mathrm{kip}=4.45 \mathrm{kN} ; 1 \mathrm{in}$. $=25.4 \mathrm{~mm}$ ).

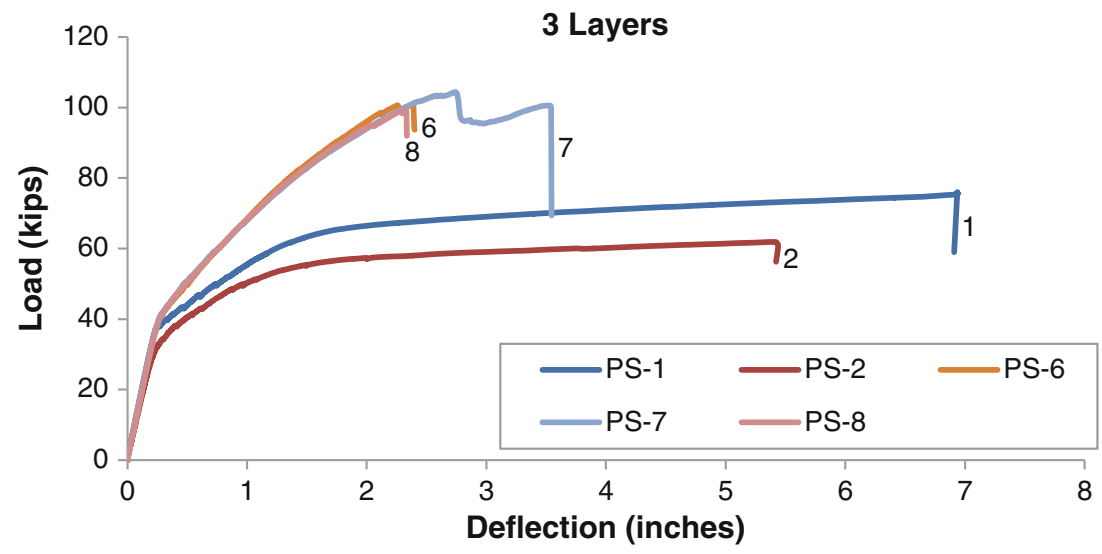

Fig. 13 Load versus deflection for controls and girders with three layers of CFRP (conversion: $1 \mathrm{kip}=4.45 \mathrm{kN} ; 1 \mathrm{in}$. $=25.4 \mathrm{~mm}$ ).

debonding of some of their U-wrappings, as shown in Fig. 20.

The half-scale girders (PS-11, PS-12, and PS-13) were intended to be tested under fatigue for 2 million cycles using a high fatigue load level of 10 kips $(44.48 \mathrm{kN})$ to $35 \mathrm{kips}$ $(155.69 \mathrm{kN})$. This high load level was applied to investigate the behavior under overloading condition. The fatigue loading was applied at a rate of $2-3 \mathrm{~Hz}$. The repaired halfscale girders were tested in several stages up to failure. After many fatigue loading cycles to simulate possible overloading conditions, the half-scale girders did not survive the desired 2 million cycles of loading. Premature failure occurred under the high level of fatigue overloading and the half-scale girders only withstood $<650,000$ cycles. That was attributed 


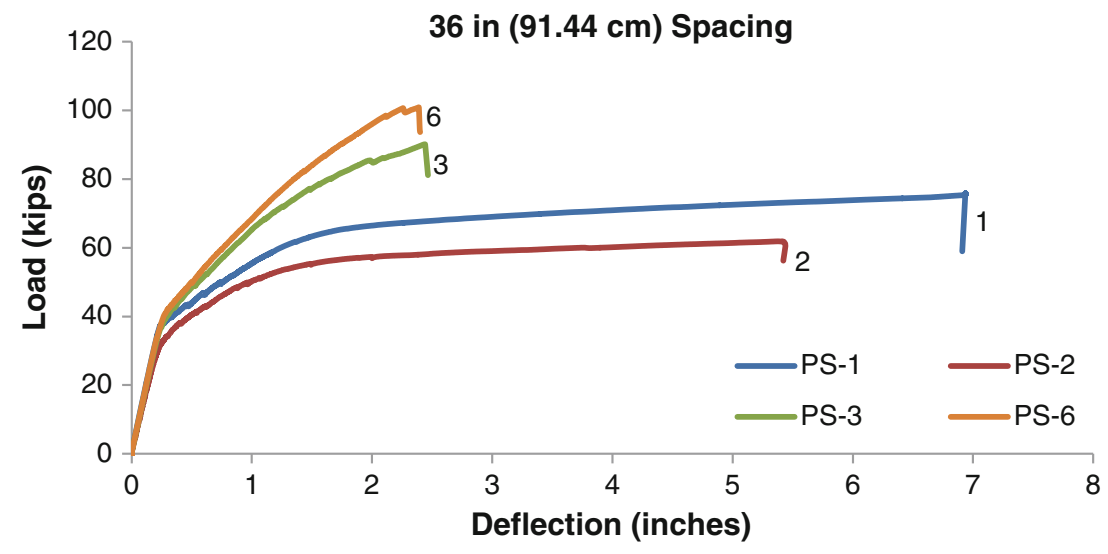

Fig. 14 Load versus deflection for controls and $36 \mathrm{in}(91.44 \mathrm{~cm})$ spacing configurations (conversion: $1 \mathrm{kip}=4.45 \mathrm{kN}$; $1 \mathrm{in}$. = $25.4 \mathrm{~mm}$ ).

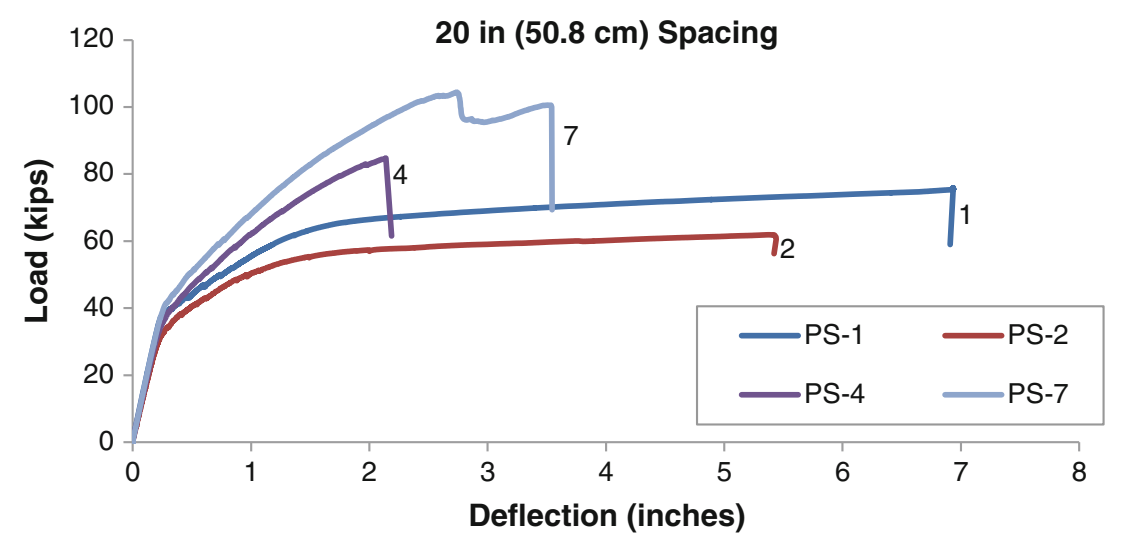

Fig. 15 Load versus deflection for controls and $20 \mathrm{in}(50.8 \mathrm{~cm})$ spacing configurations (conversion: $1 \mathrm{kip}=4.45 \mathrm{kN} ; 1 \mathrm{in}$. $=25.4 \mathrm{~mm})$.

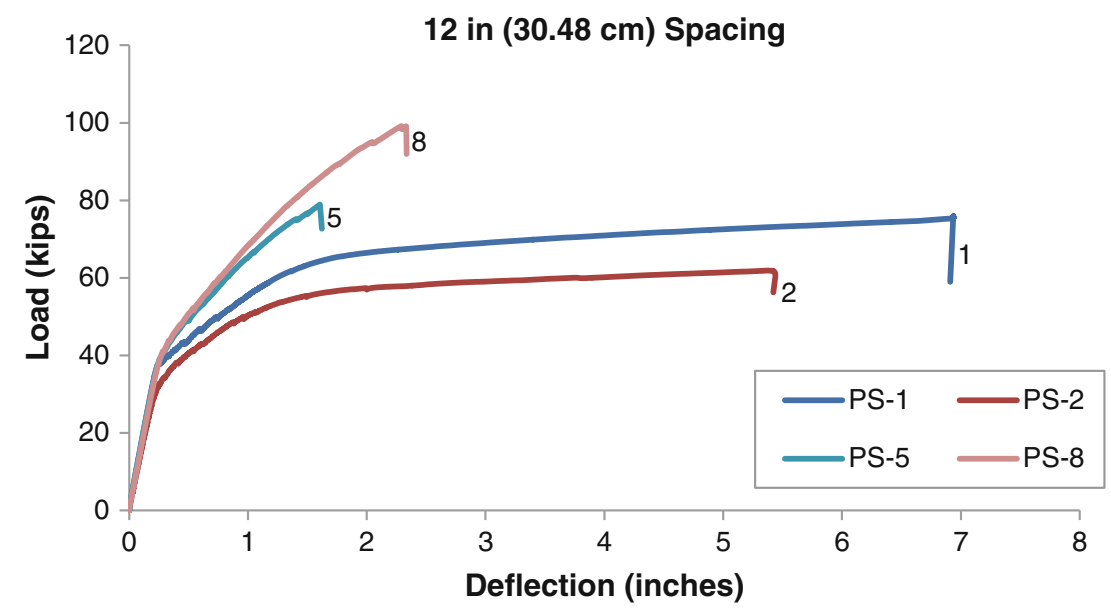

Fig. 16 Load versus deflection for controls and $12 \mathrm{in}(30.48 \mathrm{~cm})$ spacing configurations (conversion: $1 \mathrm{kip}=4.45 \mathrm{kN}$; 1 in. $=25.4 \mathrm{~mm})$.

to the high fatigue load level that exceeded the specified fatigue load level in AASHTO. There were also some deficiencies in anchoring the end of the U-wraps and in covering the induced concrete damage with a longitudinal strip to suppress crack opening. A photograph of the fatigue loading tests is shown in Fig. 21 for the half-scale girders. Figures 22, 23, and 24 show the fatigue behavior of the repaired girders PS-11, PS-12, and PS-13. Table 4 represents the test information for half-scale girders under fatigue loading including the loading rate, load range, and number of fatigue loading cycles.

\subsubsection{Strain Characteristics}

Figures 25 and 26 show the strains measured at a load level of 20 kips $(89 \mathrm{kN})$ and 70 kips $(311.5 \mathrm{kN})$. Half of the span lengths of the symmetrical girders were instrumented 


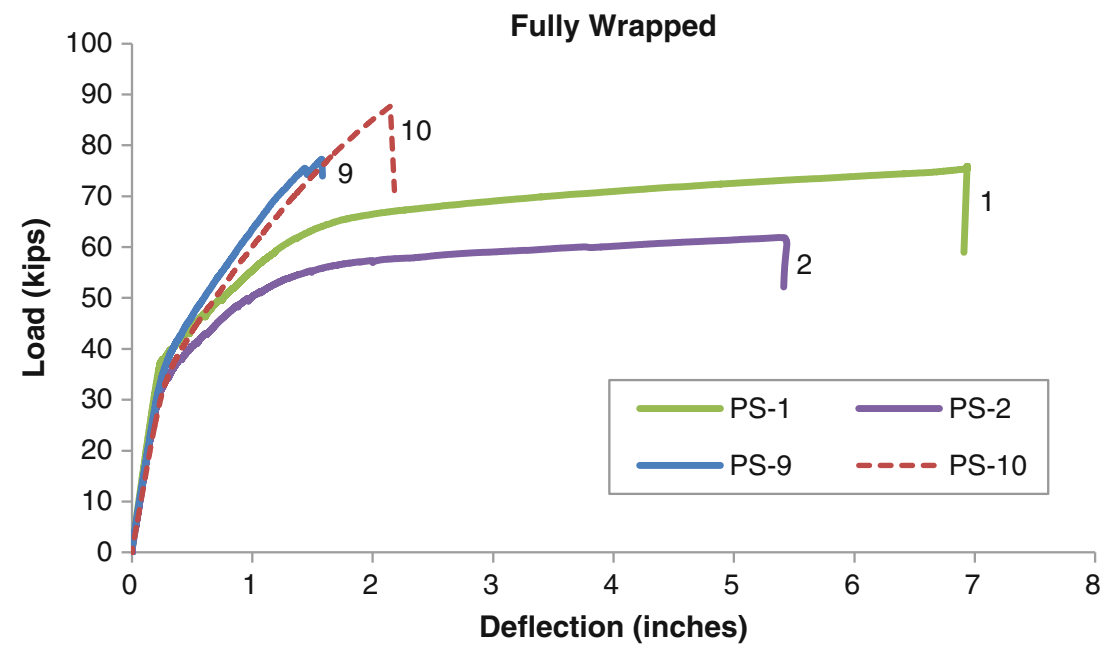

Fig. 17 Load versus deflection for controls and fully wrapped configurations (conversion: $1 \mathrm{kip}=4.45 \mathrm{kN} ; 1 \mathrm{in}$. $=25.4 \mathrm{~mm}$ ).

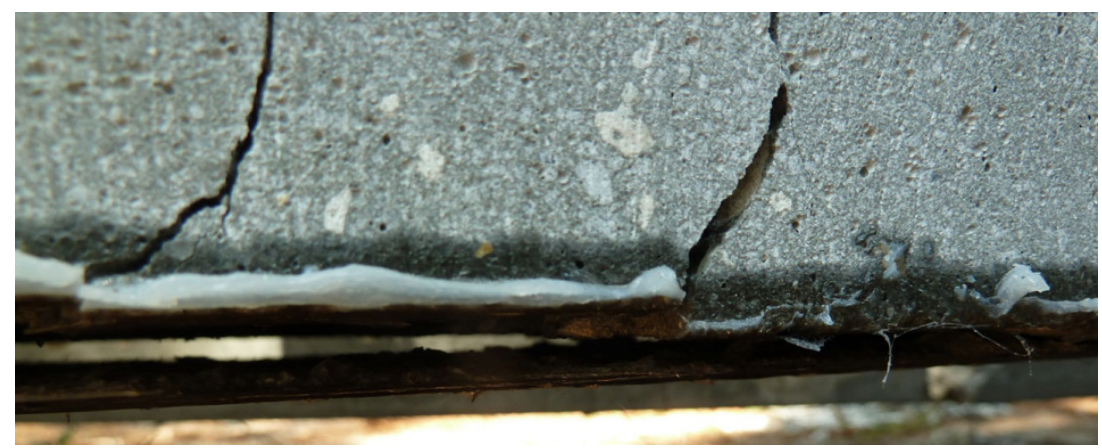

Fig. 18 Close-up of laminate debonding initiated by flexural crack development.

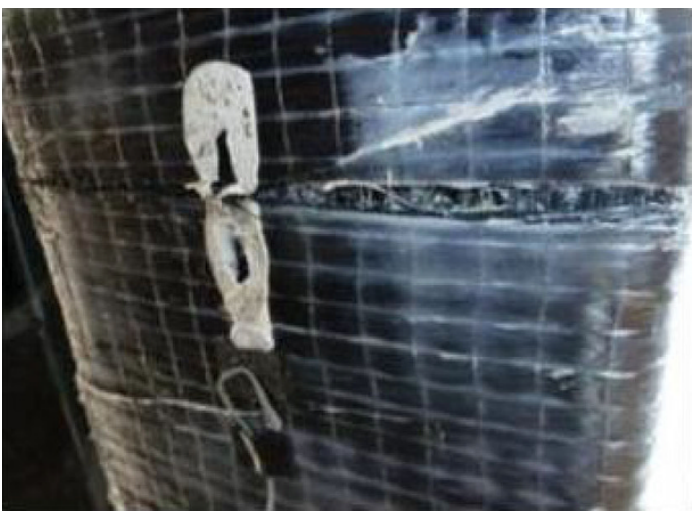

Fig. 19 Rupture of longitudinal CFRP.

with a multitude of strain gages while the other half of the span length had one strain gage.

The strains were measured at the soffit. It is evident that PS-7 [having three longitudinal CFRP layers and $20 \mathrm{in.}$ $(50.8 \mathrm{~cm})$ spacing for U-wrapping] was the most successful girder at mitigating strain development since it significantly reduced the strain developed in the longitudinal strips compared to other girders with two and three CFRP layers and with different spacing for U-wrapping. At $70 \mathrm{kips}$ $(311.50 \mathrm{kN})$, the developed strain for PS-7 was reduced by $23 \%$ compared to that of PS-4 [having two longitudinal CFRP layers and 20 in $(50.8 \mathrm{~cm})$ spacing for U-wrapping]. Also, the strains developed at 70 kips $(311.50 \mathrm{kN})$ in the

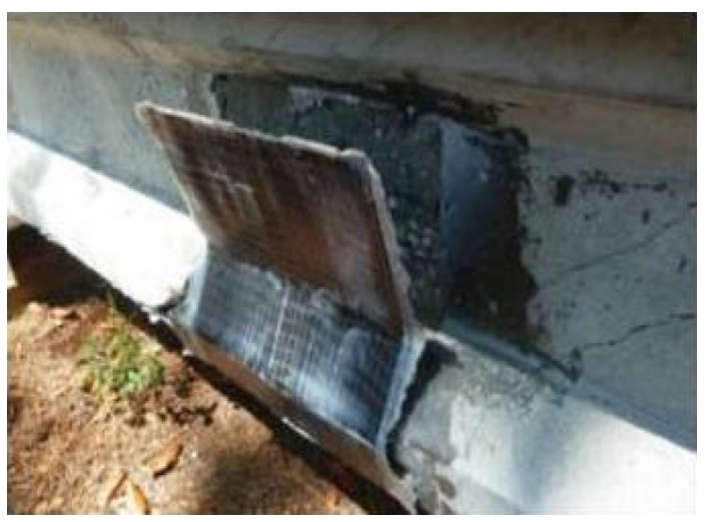

Fig. 20 Debonding of CFRP U-wrapping.

longitudinal strips for PS-7 were 6 and $11 \%$ lower than that for girders PS- 6 and PS- 8 , respectively. Table 5 shows the strain values measured at various loads for the half-scale girders.

\subsubsection{Failure Modes}

The modes of failure for the girders were recorded. The control girders PS-1 and PS-2 experienced ductile flexural failure with excessive deflection and cracking. The repaired girders experienced CFRP rupture or localized debonding followed by rupture of CFRP; as shown in Figs. 27 and 28. Figure 27 (right) shows some repaired girders that 


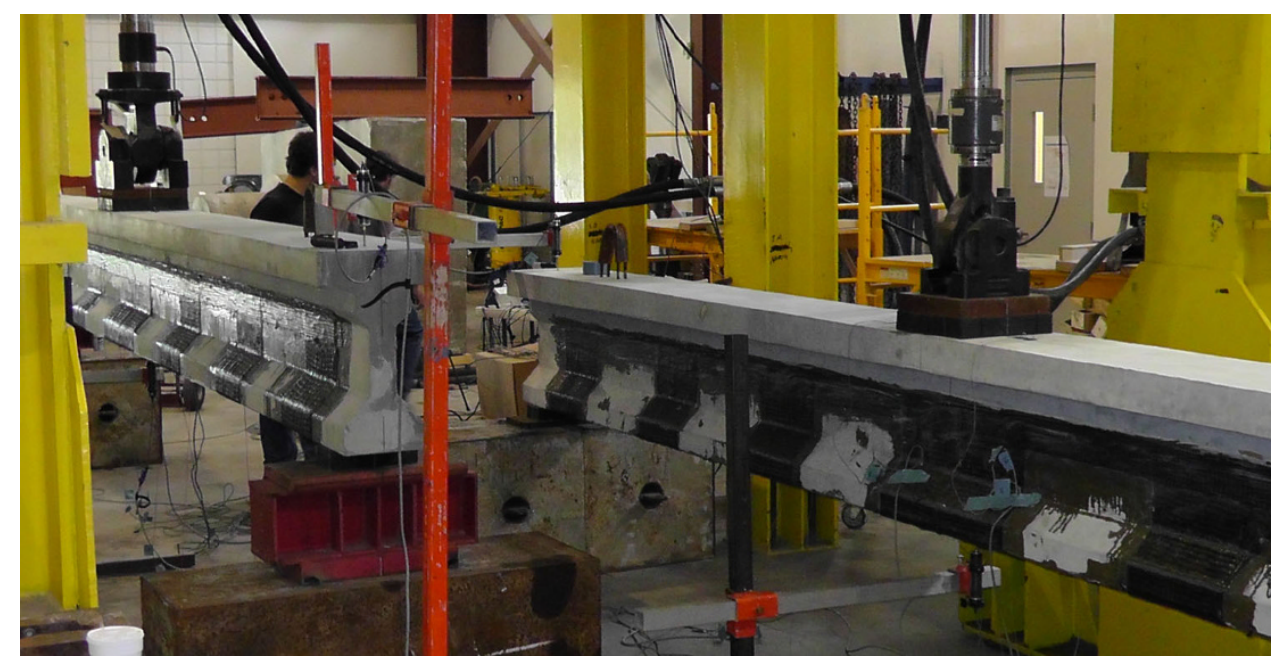

Fig. 21 Fatigue loading setup arrangement for half-scale PS girders.

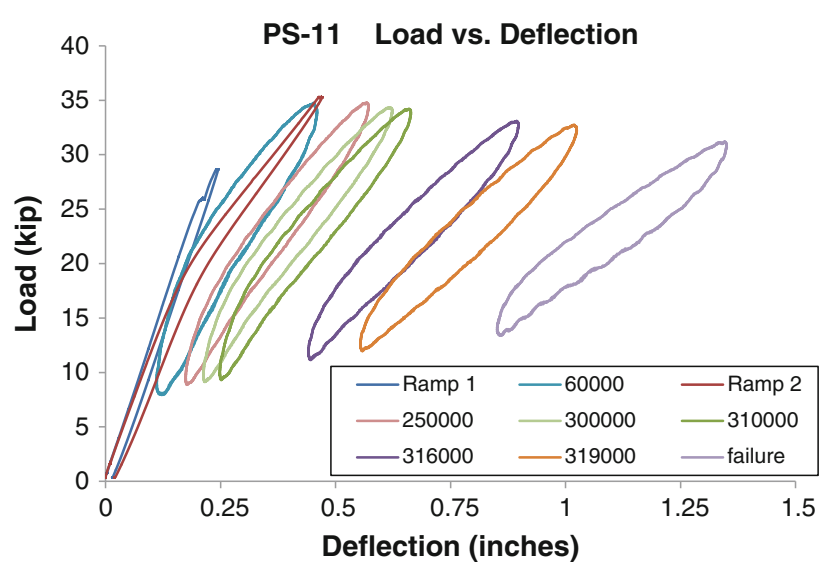

Fig. 22 Fatigue behavior and degradation until failure for girder PS-11 (conversion: $1 \mathrm{kip}=4.45 \mathrm{kN}$; $1 \mathrm{in}$. $=25.4 \mathrm{~mm}$ ).

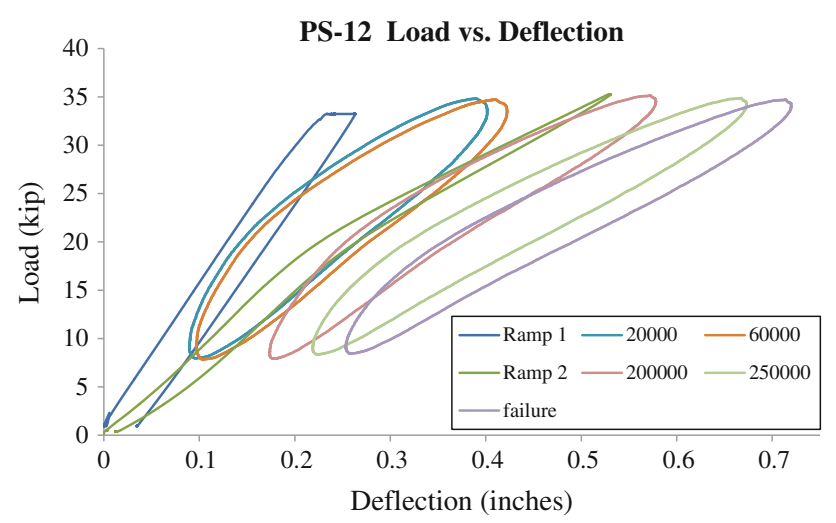

Fig. 23 Fatigue behavior and degradation until failure for girder PS-12 (conversion: $1 \mathrm{kip}=4.45 \mathrm{kN}$; 1 in. $=25.4 \mathrm{~mm}$ ).

experienced debonding of some of their U-wrappings. Figure 29 shows debonding failure of CFRP laminates for girder PS-6.

\section{Design Model and Predictions}

The ACI 440.2R-08 document (ACI Committee 440 2008) included the model used for design and capacity

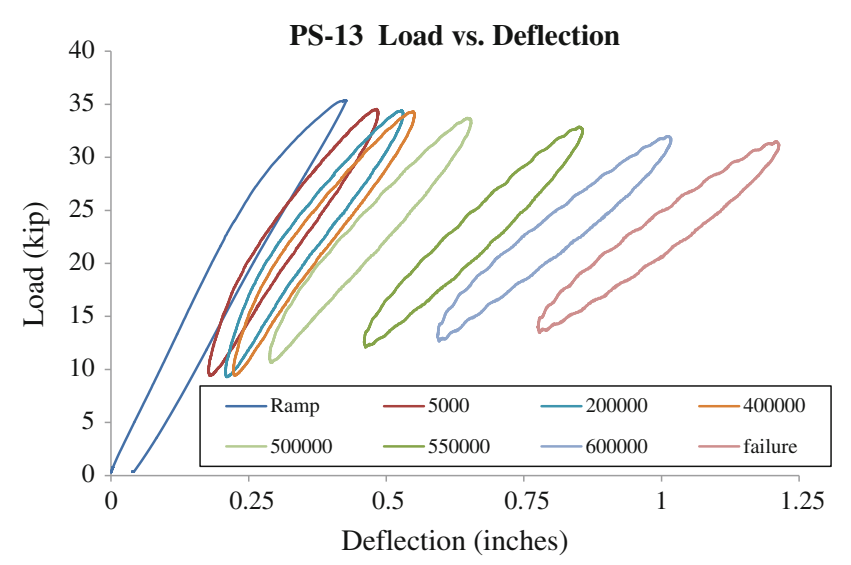

Fig. 24 Fatigue behavior and degradation until failure for girder PS-13 (conversion: $1 \mathrm{kip}=4.45 \mathrm{kN}$; 1 in. $=25.4 \mathrm{~mm}$ ).

predictions. The design equations from the design model and the resulting values for the designed repaired specimen are listed in the equations from Eqs. (1) to (9). The model identifies failure modes through the governing strain limitations due to either concrete crushing, FRP rupture, FRP debonding or prestressing steel rupture. The effective design strain for FRP rupture at a limit state controlled by concrete crushing can be calculated through Eq. (1).

$$
\varepsilon_{f e}=\varepsilon_{c u}\left(\frac{d_{f}-c}{c}\right)-\varepsilon_{b i} \leq \varepsilon_{f d}
$$

Strain values were recorded for specimens with different CFRP layers. The strain values of 0.0173 in. $/$ in. $(\mathrm{mm} / \mathrm{mm})$ and $0.0136 \mathrm{in} . / \mathrm{in}$. $(\mathrm{mm} / \mathrm{mm})$ are calculated for the test specimen with two layers and three layers of longitudinal CFRP laminates respectfully. However, $\varepsilon_{\mathrm{fd}}$ is calculated as $0.0079 \mathrm{in} . / \mathrm{in}$. $(\mathrm{mm} / \mathrm{mm})$ for two layers and $0.0064 \mathrm{in} . / \mathrm{in}$. $(\mathrm{mm} / \mathrm{mm})$ for three layers. Therefore, debonding is still the limiting factor. The ultimate limit state with rupture of the prestressing steel as the governing failure mode uses Eqs. (2) and (3) for max strain calculations. That results in a strain value of $0.0356 \mathrm{in} . / \mathrm{in}$. $(\mathrm{mm} / \mathrm{mm})$. That strain value is still greater than $\varepsilon_{f d}$, which will still control failure. 
Table 4 Fatigue testing results for the half-scale AASHTO type II girders.

\begin{tabular}{c|c|c|c}
\hline Half-scale girder designations & Loading level ranges & Loading rates & $\begin{array}{c}\text { Number of loading cycles } \\
\text { completed }\end{array}$ \\
\hline \hline PS-11 & $10-35$ kips $(44.48-155.69 \mathrm{kN})$ & $\begin{array}{c}\text { Started at } 4 \mathrm{~Hz} \text { then to } 3 \mathrm{~Hz} \text { after } \\
2,000 \text { cycles, then 2 Hz after } \\
214,000 \text { cycles }\end{array}$ & 322,000 \\
\hline PS-12 & $10-35$ kips (44.48-155.69 kN) & $\begin{array}{c}\text { Started at 4 Hz then to } 3 \mathrm{~Hz} \text { after } \\
6,000 \text { cycles, then 2 Hz after } \\
69,000 \text { cycles }\end{array}$ & 296,000 \\
\hline PS-13 & $10-35$ kips $(44.48-155.69 \mathrm{kN})$ & $2 \mathrm{~Hz}$ & 635,000 \\
\hline
\end{tabular}

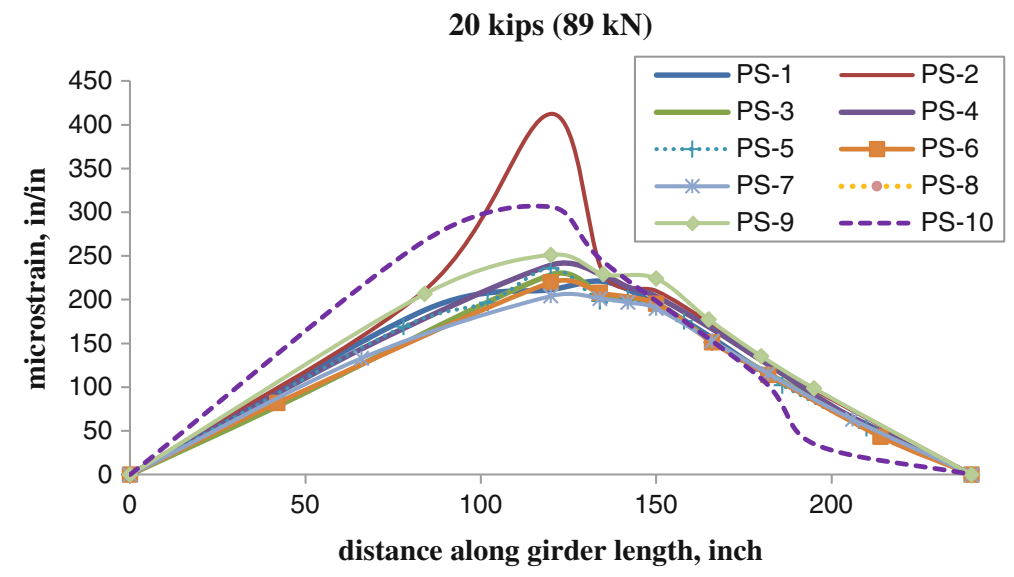

Fig. 25 Strain at extreme bottom fiber of girder soffit versus length for all girders (conversion: 1 in. $=25.4 \mathrm{~mm}$ ).

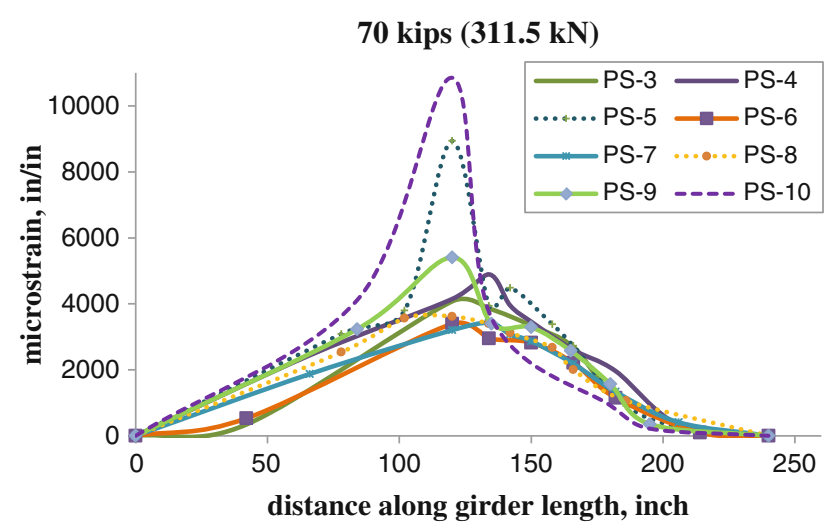

Fig. 26 Strain of CFRP at girder soffit versus length for repaired girders (conversion: $1 \mathrm{in} .=25.4 \mathrm{~mm}$ ).

$$
\begin{aligned}
\varepsilon_{f e} & =\left(\varepsilon_{p u}-\varepsilon_{p i}\right)\left(\frac{d_{f}-c}{d_{p}-c}\right)-\varepsilon_{b i} \leq \varepsilon_{f d} \\
\varepsilon_{p i} & =\frac{P_{e}}{A_{p} E_{p}}+\frac{P_{e}}{A_{c} E_{c}}\left(1+\frac{e^{2}}{r^{2}}\right)
\end{aligned}
$$

For FRP rupture or debonding as the ultimate limit state of failure, $\varepsilon_{f e}$ is chosen to be that of $\varepsilon_{f d}$ resulting in values of $110.17 \mathrm{ksi}(760 \mathrm{MPa})$ for two layers of CFRP and $89.96 \mathrm{ksi}$ $(620 \mathrm{MPa})$ for three layers for $f_{f e}$ in Eq. (4).

$$
f_{f e}=E_{f} \varepsilon_{f e}
$$

A neutral axis is assumed to be 1.69 in. (43 mm). Yet, after computing Eqs. (5) to (8), new values for " $c$ " of $3.28 \mathrm{in} . \quad(83.3 \mathrm{~mm})$ and $4.03 \mathrm{in}$. $(102.4 \mathrm{~mm})$ were determined for the two layer and three layer repairs.

$$
\begin{aligned}
& \varepsilon_{p s}=\varepsilon_{p e}+\frac{P_{e}}{A_{c} E_{c}}\left(1+\frac{e^{2}}{r^{2}}\right)+\varepsilon_{p n e t} \leq 0.035 \\
& \varepsilon_{p n e t}=\left(\varepsilon_{f e}-\varepsilon_{b i}\right)\left(\frac{d_{p}-c}{d_{f}-c}\right) \\
& f_{p s}=28,000 \varepsilon_{p s} \quad \text { for } \varepsilon_{p s} \leq 0.0086 \quad \text { in-lb units } \\
& c=\frac{A_{p} f_{p s}+A_{f} f_{f e}}{\alpha_{1} f_{c}^{\prime} \beta_{1} b} .0 .007
\end{aligned}
$$

For the girders repaired with two layers of CFRP, the final values calculated for Eqs. (5) and (7) were $0.0128 \mathrm{in.} / \mathrm{in.}$ $(\mathrm{mm} / \mathrm{mm}), \quad 0.0066$ in./in. $\quad(\mathrm{mm} / \mathrm{mm}), \quad$ and $263.07 \mathrm{ksi}$ $(1,813 \mathrm{MPa})$, respectfully. Similarly, using the three layered repair configurations, the values of $0.0116 \mathrm{in} . / \mathrm{in}$. $(\mathrm{mm} / \mathrm{mm}), \quad 0.0053$ in./in. $\quad(\mathrm{mm} / \mathrm{mm})$, and $261.21 \mathrm{ksi}$ $(1,801 \mathrm{MPa})$ were calculated for Eqs. (5) to (7). These values were all then used to calculate the theoretical ultimate 
Table 5 Strain values measured at various load levels for half-scale girders.

\begin{tabular}{|c|c|c|c|c|c|c|}
\hline \multirow[t]{2}{*}{ Girder designation } & \multicolumn{6}{|c|}{ Maximum strain values recorded at various loads } \\
\hline & $\begin{array}{c}\text { At } 5 \text { kip } \\
(22.25 \mathrm{kN})\end{array}$ & $\begin{array}{l}\text { At } 15 \mathrm{kip} \\
(66.75 \mathrm{kN})\end{array}$ & $\begin{array}{l}\text { At } 25 \mathrm{kip} \\
(111.3 \mathrm{kN})\end{array}$ & $\begin{array}{l}\text { At } 40 \mathrm{kip} \\
(178 \mathrm{kN})\end{array}$ & $\begin{array}{l}\text { At } 60 \text { kip } \\
(267 \mathrm{kN})\end{array}$ & $\begin{array}{l}\text { At } 70 \mathrm{kip} \\
(311.5 \mathrm{kN})\end{array}$ \\
\hline PS-1 & 52.58 & 158.51 & 280.33 & $291.40^{\mathrm{a}}$ & Broke & Broke \\
\hline PS-2 & 61.32 & 200.39 & 1837.30 & Broke & Broke & Broke \\
\hline PS-3 & 51.03 & 167.19 & 314.76 & $1,295.52$ & $2,984.16$ & $4,075.28$ \\
\hline PS-4 & 55.16 & 172.14 & 341.49 & $1,332.85$ & $3,197.49$ & $4,146.04$ \\
\hline PS-5 & 53.03 & 146.52 & 316.97 & $1,270.22$ & $5,213.27$ & $8,939.73$ \\
\hline PS-6 & 51.57 & 160.54 & 292.03 & $1,048.55$ & $2,646.34$ & $3,393.13$ \\
\hline PS-7 & 49.05 & 150.30 & 266.07 & 835.90 & $2,415.59$ & $3,203.85$ \\
\hline PS-8 & 52.59 & 161.94 & 281.84 & 942.62 & $2,647.17$ & $3,616.50$ \\
\hline PS-9 & 58.40 & 180.76 & 368.50 & $1,357.88$ & $3,433.54$ & 5.409 .16 \\
\hline
\end{tabular}

${ }^{a}$ Strain gauges have been determined unreliable; italic values represents lowest value recorded at that load level.
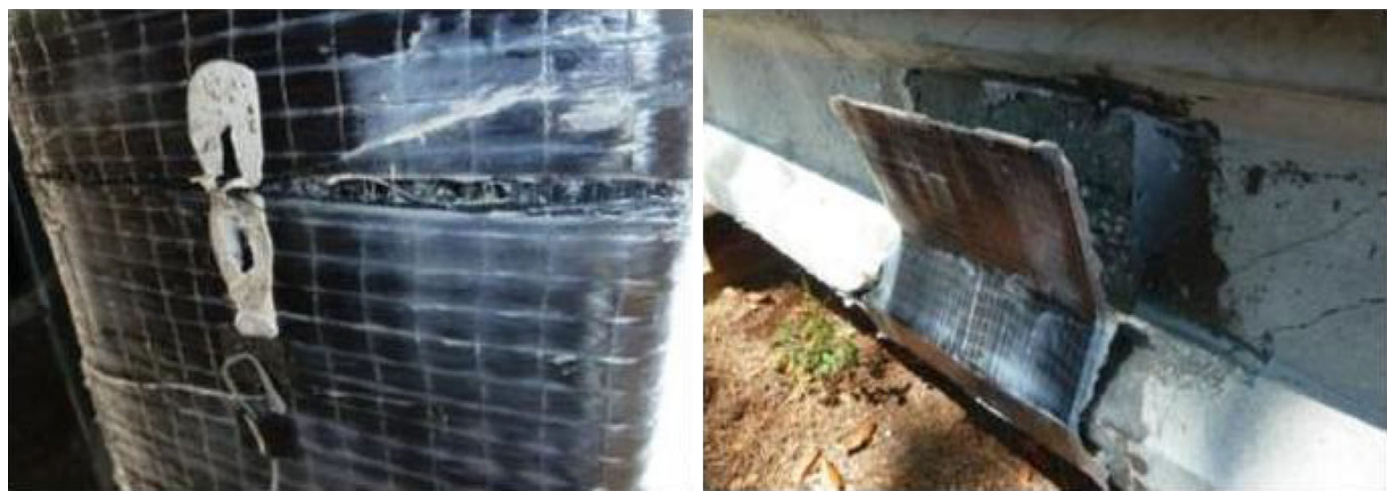

Fig. 27 (left) Rupture of longitudinal CFRP; (right) debonding of CFRP U-wrapping.
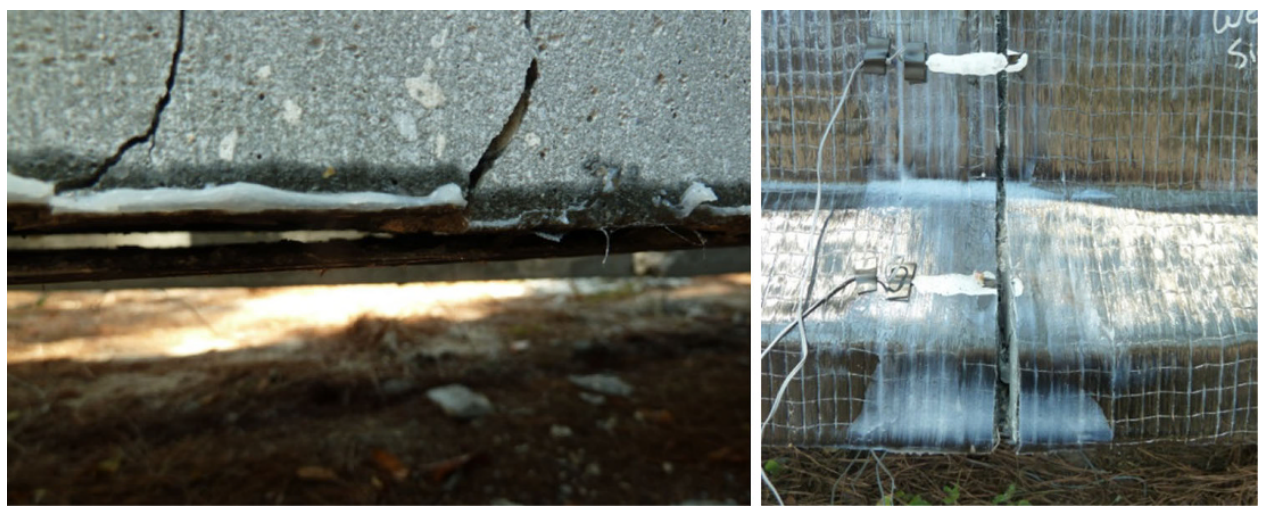

Fig. 28 (left) Debonding of soffit CFRP; (right) rupture of longitudinal and transverse CFRP.

moment capacity of the repaired girders as shown in Eq. 9, which is used in the ACI 440.2R-08.

$$
M_{n}=A_{p} f_{p s}\left(d_{p}-\frac{\beta_{1} c}{2}\right)+\psi_{f} A_{f} f_{f e}\left(d_{f}-\frac{\beta_{1} c}{2}\right)
$$

The theoretical ultimate moment capacities were $295.61 \mathrm{kip}-\mathrm{ft}(400.8 \mathrm{kN} \mathrm{m})$ and $317.3 \mathrm{kip}-\mathrm{ft}(430.2 \mathrm{kN} \mathrm{m})$ for the girders with two and three CFRP layers, respectively. These moment values indicate predicted debonding failure loads of $79.7 \mathrm{kips}(354.67 \mathrm{kN})$ and $85.6 \mathrm{kips}(380.92 \mathrm{kN})$ for the two and three layered designs, respectively. Although having intermediate U-wrappings may alter the outcomes, it is not accounted for in the ACI design provisions. Table 6 presents the predicted values of max loads and the changes compared to predictions.

As shown in Table 6, significant enhancements for the capacity of the repaired girders were recorded. Also, the analytical model predicted the maximum loads relatively 


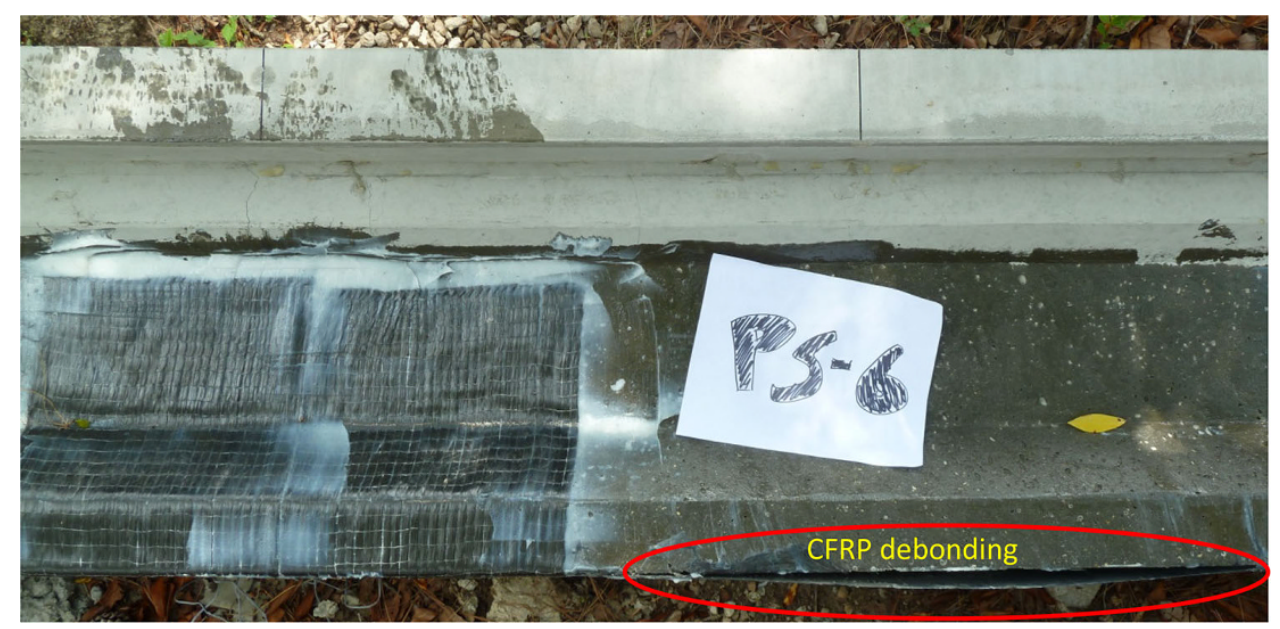

Fig. 29 Half-scale girder displaying debonding failure of CFRP laminates.

Table 6 Tested values, predictions, and comparisons.

\begin{tabular}{c|c|c|c}
\hline Girder designation & Tested max load, kips $(\mathrm{kN})$ & Predicted max load, kips (kN) & $\begin{array}{c}\text { \% increase or decrease compared to } \\
\text { prediction }\end{array}$ \\
\hline \hline PS-1 & $75.87(337.62)$ & $81.9(364.46)$ & Decreased 7.3 \\
\hline PS-2 & $61.88(275.37)$ & $66.5(295.92)$ & Decreased 6.9 \\
\hline PS-3 & $90.14(401.12)$ & $79.7(354.67)$ & Increased 13 \\
\hline PS-4 & $84.75(377.14)$ & $79.7(354.67)$ & Increased 6.3 \\
\hline PS-5 & $78.92(351.19)$ & $85.7(354.67)$ & Increased 17.8 \\
\hline PS-6 & $100.91(449.05)$ & $85.6(380.92)$ & Increased 21.9 \\
\hline PS-7 & $104.42(464.67)$ & $85.6(380.92)$ & Increased 15.8 \\
\hline PS-8 & $99.16(441.26)$ & $79.7(354.67)$ & Decreased 3.1 \\
\hline PS-9 & $77.26(343.81)$ & $79.7(354.67)$ & Increased 10.0 \\
\hline
\end{tabular}

close to the test values of failure loads in several repaired and control girders.

\section{Conclusions}

The ACI 440.2R-08 indicated that for shear strengthening using external FRP reinforcement in the form of discrete strips, the center-to-center spacing between the strips should not exceed the sum of $d / 4$ plus the width of the strip. However, it should be noted that this presented study addressed the U-wraps used primarily for flexural repair without consideration for shear strengthening. After analyzing the results and behaviors of the specimens the following conclusions can be drawn:

1. CFRP repair systems can be applied in different configurations, discrete U-wrap, or full wrapping of the girder web. Evenly spaced transverse U-wrappings provide an efficient configuration for CFRP flexural enhancement repairs that mitigate debonding. When repairing laterally damaged girders having a loss of prestressing steel reinforcements it is necessary to cover the damaged section with longitudinal and transverse strips to reduce the crack propagation in the critical region which initiates early debonding.

2. Externally bonded FRP U-wrapping could debond and result in premature failure if there is no proper anchorage system. Anchorage for the U-wraps prevents premature debonding of the FRP wraps, resulting in a greater increase of the ultimate flexural capacity.

3. If CFRP shear enhancements are not needed, the configuration of discrete transverse U-wraps with spacing between them provides comparable flexural benefits to a fully wrapped girder. If shear improvement is not needed, spacing for discrete transverse wraps can be between a distance of one half to one times the depth of girder to constitute a safe CFRP repair. However, without consideration for shear enhancements, a more conservative spacing for transverse anchoring is recommended to be around one half the height of the girder.

4. The damage and cutting of one of the prestressing strands (Girder PS-2) resulted in $18.44 \%$ loss in flexural capacity compared to the undamaged control girder. The CFRP repair of the damaged girder restored its capacity and exceeded the capacity of the undamaged 
intact control girder with no cut strand by up to $37.63 \%$.

5. A comparison between the failure load of control girder (with cut strand and un-strengthened with CFRP) and repaired girders with 2 layers of CFRP shows that CFRP repair enhanced the flexural capacity by $27.53-45.66 \%$ compared to control girder (with cut strand and unstrengthened with CFRP). For repaired girders with three layers of CFRP, increases in the flexural capacity were reported to range from 60.24 to $68.74 \%$ compared to control girder (with cut strand and un-strengthened with CFRP). An increase in the failure load of 24.85-41.69\% was observed for the two-layered fully CFRP wrapped repaired girders compared to the unstrengthened control girder. The CFRP repaired girders fail prematurely at $<1$ million cycles under overload fatigue conditions and improper CFRP anchoring.

6. Proper CFRP repair design in terms of the number of CFRP longitudinal layers and U-wrapping spacing could result in obtaining significant enhancement for the capacity and desired failure modes for the repaired girders. Favorable failure modes of the repaired girders can be maintained using a CFRP repair configuration utilizing spacing between the U-wrappings to prevent undesirable modes of failure such as debonding of the longitudinal CFRP strips from the girder concrete soffit.

\section{Open Access}

This article is distributed under the terms of the Creative Commons Attribution License which permits any use, distribution, and reproduction in any medium, provided the original author(s) and the source are credited.

\section{References}

ACI Committee 440. (2008). ACI 440.2R-08 Guide for the design and construction of externally bonded FRP systems for strengthening concrete structures (p. 80). Farmington Hills, MI: American Concrete Institute.

Choi, D.-U., Kang, T. H.-K., Ha, S.-S., Kim, K.-H., \& Kim, W. (2011). Flexural and bond behavior of concrete beams strengthened with hybrid carbon-glass fiber-reinforced polymer sheets. ACI Structural Journal, 108(1), 90-98.

Di Ludovico, M. (2003). Experimental behavior of prestressed concrete beams strengthened with FRP, Report CIES 03-42. Rolla, MO: University of Missouri.

ElSafty, A., \& Graeff, M. (2011). Investigating the most effective CFRP configuration in repairing damaged concrete beams due to collision, The 13th International Conference on Civil, Structural and Environmental Engineering Computing, Crete, Greece.

ElSafty, A., \& Fallaha, S. (2013). Behavior of laterally damaged bridge girders repaired with CFRP laminates under fatigue and static loading. Washington, DC: Transportation Research Board (TRB).

Fu, C. C., Burhouse, J. R., \& Chang, G. L. (2003). Study of overheight vehicles with highway bridges, Transportation research board.

Grace, N. F., Ragheb, W. F., \& Abdel-Sayed, G. (2003). Flexural and shear strengthening of concrete girders using new triaxially braided ductile fabric. ACI Structural Journal, 100(6), 693.

Green, P. S., Boyd, A. J., \& Lammert, K. (2004). CFRP repair of impact-damaged bridge girders, Vol. I: Structural evaluation of impact damaged prestressed concrete I girders repaired with FRP materials, $B C-354$ RPWO \#55, Florida Department of Transportation.

Ibrahim Ary, M., \& Kang, T. H.-K. (2012). Shear-strengthening of reinforced and prestressed concrete beams using FRP: Part I-Review of previous research. International Journal of Concrete Structures and Materials, 6(1), 41-48.

Kang, T. H.-K., \& Ibrahim Ary, M. (2012). Shear-strengthening of reinforced and prestressed concrete beams using FRP: Part II-Experimental investigation. International Journal of Concrete Structures and Materials, 6(1), 49-57.

Kasan, J. L. (2009). Structural repair of prestressed concrete bridge girders, MSCE Thesis, University of Pittsburgh, PA.

Kasan, J. L., \& Harries, K. A. (2009). Repair of impact-damaged prestressed concrete bridge girders with carbon fiber reinforced polymers, Asia-Pacific Conference on FRP in Structures, Seoul, Korea.

Klaiber, W. F., Wipf, T. J., \& Kempers, B. J. (2003). Repair of damaged prestressed concrete bridges using CFRP, MidContinent Transportation Research Symposium, Iowa State University, Ames, IA.

Nanni, A., Huang, P. C., \& Tumialan, J. G. (2001). Strengthening of impact-damaged bridge girder using FRP laminates”, 9th International Conference, Structural Faults and Repair. London, UK: Engineering Technics Press.

NCHRP R-514. (2004). National Cooperative Highway Research Program. Bonded repair and retrofit of concrete structures using FRP composites: recommended construction specifications and process control manual, Washington, DC.

NCHRP R-655. (2010). National Cooperative Highway Research Program. Recommended guide specification for the design of externally bonded FRP systems for repair and strengthening of concrete bridge elements, Washington, DC.

Razaqpur, G. A., \& Isgor, B. (2006). Proposed shear design method for FRP-reinforced concrete members without stirrups. ACI Structural Journal, 103(1), 93.

Rosenboom, O., \& Rizkalla, S. (2007). Analytical modeling of flexural debonding in CFRP strengthened reinforced or prestressed concrete beams. Proceedings of the 8th International Symposium on Fiber Reinforced Polymer Reinforcement for Concrete Structures (FRPRCS-8).

Schiebel, S., Parretti, R., \& Nanni, A. (2001). Repair and strengthening of impacted PC girders on bridge, Report A4845, Missouri Department of Transportation. 
Shanafelt, G. O., \& Horn, W. B. (1980). Damage evaluation and repair methods for prestressed concrete bridge members, NCHRP Report 226, Project No. 12-21, Transportation Research Board, Washington, DC.

Shanafelt, G. O., \& Horn, W. B. (1985). Guidelines for evaluation and repair of prestressed concrete bridge members, NCHRP Report 280, Project No. 12-21(1), Transportation Research Board, Washington, DC.

Shin, Y., \& Lee, C. (2003). Flexural behavior of reinforced concrete girders strengthened with carbon fiber-reinforced polymer laminates at different levels of sustaining load. ACI Structural Journal, 100(2), 139.

Stallings, J. M., Tedesco, J. W., El-Mihilmy, M., \& McCauley, M. (2000). Field performance of FRP bridge repairs. Journal of Bridge Engineering, 05(5), 107-113.

Tumialan, J. G., Huang, P. C., \& Nanni, A. (2001). Strengthening of an impacted PC girder on bridge A10062, Final Report RDT01-013/RI99-041, Missouri Department of Transportation. 